\title{
An Evaluation of the Effectiveness of Environment Policy in Jordan
}

\author{
Adel Yacob Shamaileh ${ }^{1}$ \\ ${ }^{1}$ Department of Public Administration, University of Jordan, Jordan \\ Correspondence: Adel Yacob Shamaileh, Department of Public Administration, University of Jordan, Jordan. \\ E-mail: a.shamaileh@ju.edu.jo
}

Received: July 11, 2015

Accepted: December 8, 2015 Online Published: January 23, 2016

doi:10.5539/ijbm.v11n2p92

URL: http://dx.doi.org/10.5539/ijbm.v11n2p92

\begin{abstract}
This study examines the impact of environmental policy in Jordan. The article evaluates the implementation process and reviews the policy measures, instruments and their effectiveness in banning, removing and/or reducing negative externalities in Jordan. Data was provided through analysis of responses to questionnaires distributed to all key enforcement officials working in the Ministries of Environment, Agriculture and Health. Additional sources were laws, regulations, official documents and reports issued by the government.

The study shows that Jordan's environmental policy relies solely on the command and control approach to mitigate negative externalities, while completely overlooking price-based and rights-based instruments. Such instruments are widely and increasingly employed in developed countries and have proved their efficiency and effectiveness in protecting the environment. The results of the study reveal that command and control measures are insufficient to achieve effective environmental policy. Consequently, they are incapable of internalizing negative externalities in Jordan. The three ministries were ineffective in both monitoring and enforcement, which are essential for the success of environment policy. Results may motivate government regulators to endorse price-based and rights-based measures, in addition to command and control measures.
\end{abstract}

Keywords: price based instruments, command and control instruments, deterrence, enforcement, compliance, regulation

\section{Introduction}

This study examines the experience of Jordan in the area of environmental policy and practice. The analysis measures the effectiveness of monitoring and enforcement approaches adopted and implemented by three ministries to achieve environmental compliance. More precisely, the aim is to determine whether inspections, penalties and other enforcement tools of the command and control approach are effective in changing the behaviour of polluters, which set of tools contribute more, and whether general deterrence is a critical factor in stimulating overall compliance.

Negative externalities cannot be totally eliminated and hence exist in all countries, with variation in the degree of environmental harm. Although worldwide awareness and concern of the impact of negative externalities on the environment and the quality of life started by the mid- $20^{\text {th }}$ Century, negative externalities are not a new phenomenon or merely a side effect of industrialization.

Nevertheless, the magnitude of negative externalities has become a real threat to quality of life and development sustainability, largely due to rapid growth in industrialization and urbanization. The discovery and production of comparatively low-cost fossil fuel has contributed to the immense growth and expansion in industry, transport, agriculture and service sectors. This growth, in turn, has led to intensive use and misuse of natural resources. The outcome of these developments is continuously increasing per capita emissions.

In Jordan, many factors have contributed to the increase in size and diversity of negative externalities, including: unprecedented population growth, rapid urbanization, industrialization and the diversification of services. The expansion of agricultural activity, facilitated by the adoption of new technologies, use of insecticides and fertilizers to meet internal and external demand has also contributed to the problem. Furthermore, an increasingly mobile lifestyle, evolving consumption and production patterns and the use of outdated technology and machinery by industries, have also been contributing factors to the level of negative externalities in Jordan.

Growing worldwide concern about the tremendous threats to the environment, often caused by uncontrolled 
behaviour and practices of individuals and firms, has made it an urgent requirement for governments to take action to protect the environment. In Jordan, the government response has been verbally strong, but on the ground, slow and inadequate. Political economy plays a role in non-decisive government action. For political stability, the priority of government is the availability of goods and services at low prices in addition to job opportunities to safeguard a minimum standard of living. As such, for a long time the government has turned a blind eye to the quality of goods and services and the impact of their production and delivery on the environment. Ultimately however, environmental issues have come to the forefront of the policy agenda in Jordan thanks to external pressure.

Environmental policy agenda encompasses most sources and symptoms of pollution, including: air, water, and noise pollution, deforestation, improper use of fertilizers and pesticides (which decrease soil and ground water quality), conservation of biodiversity, dust and waste from construction and carbon intensity in the residential and transport sectors.

This study is based on a survey of the perception of key officials in the ministries of Environment, Agriculture and Health who are responsible for implementing the regulations. This survey assesses the impact of enforcement alternatives on compliance and violations. The study also presents and analyses data from government documents and annual reports

\subsection{Research Questions}

The study intends to answer the following questions:

a. To what extent has the environmental policy in Jordan achieved its goals? In other words, what is the impact of command and control instruments on change in the magnitude of negative externalities?

b. What difference did regulations have in terms of problem-solving?

c. Have the specified remedies worked?

d. Which enforcement measures proved to have a significant impact?

e. What is the degree of government commitment towards implementing its environmental policy?

\subsection{The Importance of the Study}

Eleven years have elapsed since the adoption of environmental law and the foundation of the Ministry of Environment to confront these issues: it is important to measure the results. Eleven years are sufficient to achieve measurable progress. Considerable resources were allocated annually to the ministry. These always have an opportunity cost, especially in a country with limited resources. Environmental regulations are enacted to achieve outcomes by changing individuals' and firms' irresponsible conduct. Any policy that does not achieve its goals is of no value and leads to unnecessary costs on the economy and humans.

Despite the importance of the issue, there has not yet been an independent, neutral assessment of the effectiveness of environmental policy in Jordan. Therefore, this study attempts to fill the gap in the literature, and to provide insight into what has been achieved thus far.

\subsection{Article Organization}

This study is organized as follows: Section One provides the literature review; Section Two focuses on the methodology, data sources and description; Section Three presents data analysis and results; Section Four provides key findings, recommendations and conclusions.

\subsection{Literature Review}

A detailed literature review on the effectiveness of environmental regulations identified methods that have had a positive impact on the outcome of environmental policies.

The literature review covers the following items:

a. Procedural definitions.

b. Alternative policies to control, mitigate and internalize negative externalities.

c. Compliance and enforcement mechanisms.

\subsection{Procedural Definitions}

Environment is "used in reference to human interaction with the ecosystem. To increase precision, it thus seems reasonable to view 'environmental' as a subset of the broader concept of 'ecological', i.e., the intersection of human activities and an ecological system" (Morelli, 2011, p. 5). 
Air pollution is defined as "the release into the atmosphere of particulate toxic elements by natural or anthropogenic sources" (Zell, 2010). "Emission limit values' means the mass, expressed in terms of certain specific parameters, concentration and/or level of an emission, which may not be exceeded during one or more periods of time" (The European Parliament and The Council of European Union, 2008).

Regulations constitute laws, by-laws, directives, rules, procedures and practices related to a specific policy (OCEC, 2010).

Pollution prevention can be defined as "the elimination or reduction of harmful wastes and pollutants at their origin: the act of reducing or eliminating the use, release or generation of a pollutant or potential pollutant through source reduction, recycling, reuse, reclamation or modification of existing practices." (EPA, 1990).

Licensing is government authorization to engage in a business or profession or to do something otherwise banned.

Sanctions are devices and penalties enforced to encourage or compel compliance.

Evaluation studies focus on policy design, adoption, implementation and outcome or output. The results should point out the relevance and achievement of objectives of the policy using indicators such as: impact, enhancement of efficiency, or the degree of effectiveness (Young, 2000), (Rist, 2004). Assessment of the effectiveness of enforcement measures is result-oriented. It examines the influence of the entire process including inspection, detection and penalties (Thornton D. N., 2005).

Environmental indicators are simple measures of performance (OECD data sources, 2013).

\section{Literature Review}

Negative externalities emerge when a transaction between two or more parties in the market imposes harm or unwanted effects on others not involved or interested in that transaction, and who have received no reward or benefit from its occurrence. Examples of negative externalities include: second-hand smoking; air pollution from factories, workshops, private and public transportation systems; energy production; illegal dumping of wastes in waterways and/or near water sources; unregulated disposal of solid wastes; noise pollution; deforestation; excessive hunting of wild birds and animals; and threats to genetic diversity. In most instances, the phenomenon is a result of production (and consumption) of goods and services (Ciegis \& Pusinaite, 2010); (Defu, 2013).

Prices of goods and services play decisive roles in the emergence of negative externalities because there is a negative relationship between price and demand. Consumers are usually willing to buy more at a lower price to maximize their utility. Consequently, producers driven by profit maximization respond positively to the increase in demand by increasing the supply (production). On the opposite side, there is a positive relationship between quantity of production (consumption) and negative externality: the more the production (consumption), the more the harm. Hence, the solution to negative externality is to reverse the course of action by setting the appropriate mechanisms to correct the pricing policy to internalize the marginal damage to the society. The required action is increasing the price to become equal to social marginal cost to reflect its true cost to the society:

\section{Price $=$ Social marginal cost instead of Price $=$ Private marginal cost}

Because increasing the price of goods and services ultimately reduces consumption of goods and services (demand), thus the production and supply will fall and consequently negative externality (Ciegis \& Pusinaite, 2010); (Brocas, 2013). The magnitude of negative externality (marginal damage) depends to a great extent on the divergence between private marginal cost and social marginal cost (Krause J. K., 1997); (Gruber, 2011); (Quality, 2004). Public finance theorists consider negative externality as a source of market failure because it leads to inefficient allocation of resources (Tresch, 2008); (Christiansen, 2013); (Macie \& Maruyama, 2012). According to most economists, except right wing conservatives, environmental protection to control negative externalities is the responsibility of governments since the private sector is the main source of threat to the environment. Economic research reports the last decade's experience of developed and many developing countries of the most efficient and effective deterrent techniques (Boyan, 1992); (Ostrom, 2002); (Winston, 2007); (Mazmanian, 2009).

There are two sets of policy alternatives. First is command and control regulations. The second is economic theory-based policies. Most countries, especially developed countries, begin with adopted command and control regulations. Since the 1980s the trend has been changing in line with the advice of economists and findings of economic research to use market-based instruments. The choice between the two approaches depends on the judgment of efficiency and cost-effectiveness of each approach (Gaulding, 1995); (Portney, 2000); (Morgenstern, 2004); (Calel, 2009). 
Command and control regulations aim to force firms to employ specific technology to achieve the reduction magnitudes set by government authorities. This method relies on coercive methods such as banning and revoking licensing (Whitehead, 1996); (Meffe, 1996); (Kompas \& Gooday, 2007). Command and control instruments are considered rigid because they deny firms the right to look for and apply better methods to respond to government directives. They deter the development of more advanced and appropriate technologies that have the potential to reduce the undesired level of pollution to an acceptable amount. In addition, they impose the same treatment on all firms regardless of the differences in their size, quantity of pollution they emit and per unit cost of the procedure. The conclusion is that the command and control approach is cost-ineffective and mostly falls short of attaining the prescribed goals (Whitehead, 1996).

The majority of economists support the adoption of price-based and right-to-pollution policies because they are the most cost-efficient policies to internalize negative externalities at a reasonable cost, especially when the estimated costs represent a heavy burden (Fullerton, Leicester, \& Smith, 2008); (Kuminoff, 2007). According to (Stavins, Lessons From the American Experiment With Market-Based Environmental policies, 2001) economic-based policies allows: the burden of pollution control to be shared more efficiently among businesses'.

The economic-based approach intends to internalize negative externalities. It provides four alternatives: first, Pigouvian taxes which take the form of: per-unit, fees, excise, specific sales, or targeted value-added, congestion and vehicle excise, landfill, carbon, and tax on plastic bags to ban its consumption. These are just examples of the application of tax policy in different countries of the world. The impact of this instrument varies with the percentage of tax. This must be high enough to increase the price and to offset inelasticity in demand and supply (Guerin, 2003); (UNEP, 2004); (Anderson, 2002).

Second, rights-based measures. These take one of two forms: a. Tradable pollution rights, b. Cap and trade (Stavins, 2001).

Applying tradable pollution rights (marketable permits) requires environmental agencies to arrive at the level of pollution that can be accommodated in each specific area and then allocate the estimated pollution up to that level, to firms in that area equally, regardless of their actual emissions. Firms with low emissions can sell their shares to firms that pollute more if they find it cheaper for them than other alternatives (Ulbrich H. H., 2011). Choosing cap and trade method, the authorities must issue permits up to the cap they choose and then sell them in an auction to firms in the area. Firms and individuals who buy these permits reserve the right to resell all or part of the permit to firms and individuals that pollute more than they are permitted (Calel, 2009). A tradable pollution right is one of the decentralized methods for controlling negative externalities. Ellerman (2005) classified Tradable permits into the following alternatives: credit trading, averaging and allowance trading. According to Ellerman, cap leads to two consequences. First, the regulator's role is just to set a cap representing the optimal quantity of emissions without detailed specifications; then to specify a space and time frame. Second, the rights to discharge should be explicit and without restriction on their owners (Ellerman, 2005). This method of controlling negative externalities can achieve environmental goals without significant government intervention and at a low cost (Zasloff, 2013).

The fourth form of economic-based mechanisms for constraining negative externalities is applying Coase Theorem: Coase argued that once property rights are assigned, rational participants involved in an inefficient allocation can settle the negative externality without government intervention through negotiation (Ulbrich $\mathrm{H}$. H., Public Finance in Theory and Practice, 2011).

\subsection{Enforcement and Compliance}

Most environmental policies have two components. First, goal adoption; second, the means to realize the established goal. Compliance refers to change by polluters in their way of thinking, practices, technologies they employ, input and output quality and quantity, pricing policy to meet their legal obligations and avoid penalties. Compliance enforcement is designed to cause people to do things, cease doing things, or continue to do things (Anderson, 2010). Compliance under the threat of the use of criminal prosecutions must be considered only as the last resort by government agencies. Deterrence is critical to the success of environmental policies, because it makes companies recognize the consequences of their illegal behaviour (ibid).

The classical theory of deterrence according to Quality (2004) recommends the following determinants of enforcement. First, certainty of penalty for offenders. Second, the penalty must be seen as severe enough by violators in order to make them consider, respect and obey the regulations. Third, reliable legal authority to firmly implement the law and removing the possibility for leniency or wavering in executing penalties: on-the-spot fines provide credible deterrence at a very modest administrative and legal cost, and public disclosure (Decker, 2005); 
(The World Bank, 2000). Fourth, authorities should act rationally in applying enforcement. Fifth, the success of the administration depends to a large extent on the qualifications and attitudes of the personnel in general and professionals in particular, and the collaboration of governmental institutions (Andrews., 1993); (Helmut, 2002) and on how well the officials in the regulatory institution implemented the regulatory policy (Stéphane, 2007).

It also requires effective organizational capacity-building to establish a firm and capable national control regime based on collective efforts among relevant departments. Lack of incentives, incapable organizations, lack of professionalism and motivation on the part of enforcement agencies reduces compliance level (EPA, 2007); (Earnhart R. L., 2008). Sixth, improving case processing times. Seventh, the degree and consistency of compliance is a function of enforcement persistence, quality and comprehensiveness. Firms vary in their understanding and response speed and level. Eighth, ambiguous laws, corruption, conflict and competition among numerous players and ineffective monitoring systems are counterproductive elements. Ninth, appropriate definition of environmental problems, reliance on clear standards and indicators and limits (OECD, 2000), (DEFRA, 2006).

Empirical research has not reached a preference of one method over the others (Lubell, 2009). The consequence of weak monitoring leads to high rates of violation of environmental standards. Because monitoring is the most costly instrument, regulators substitute direct monitoring with self-monitoring (Russell, 1990). The command and control approach to environmental regulation requires tighter monitoring of compliance to compensate for lack of incentives, and relies only on enforcement action against non-compliers (Gunningham, 1994); (Davies, 1998); (Russell, 1990).

Research findings suggest that large firms, monopolies and businesses owned or run by influential persons and unions tend to comply less. They exceed permitted limits and pay no attention to inspections (Rassire, 2006; Gray, 2005; Gunningham, 2005; Foulon, 2002). Rassier D. G. (2006) found unionized plants and those with relatively strong unions discharge more pollution than non-unionized and relatively weak unions' plants (Gray \& Shadbegian, 2005; EPA, 2007).

Harrington and Morgenstern (2004) tested five hypotheses to examine which of the two competitive approaches, Command and Control vs. Economic Based Methods, are more effective and efficient in implementing public policies to mitigate negative externalities. They tested whether the hypothesis is confirmed in one or more of the twelve case studies they conducted in the USA and Europe. In general, with some exceptions, economic instruments proved to be more attractive on both scales: effectiveness and efficiency. The study also indicated that elements of both approaches exist in most environmental policies in USA and Europe. Whitehead and Stavis (1995) stated that: meeting the expectations from market-based instruments requires: realistic expectations, political will, avoiding design flaws and appropriateness of company skills.

\subsection{The Institutional Framework of Environment Protection in Jordan}

The government of Jordan has joined the global environmental protection campaign by signing international environment protection agreements and commitments, namely: biodiversity, climate change, climate change-Kyoto protocol, desertification, endangered species, hazardous wastes, law of the sea, marine dumping, ozone layer protection and wetlands protection. Actions have been exerted by the government to translate its commitment of protecting the environment and conservation of natural resources by enacting laws and regulations and establishing agencies responsible for implementing them.

Protection of the environment in Jordan is the responsibility of the following ministries: Ministry of Health, Ministry of Water and Irrigation, Ministry of Municipalities Affairs, Ministry of Environment, Ministry of Industry and Trade, Ministry of Agriculture, Ministry of Transportation, Ministry of Energy and Natural Resources, criminal investigation and law enforcement agencies, Customs Department and Royal Environmental Police. Each one of them still executes the articles of its own law and regulations related to the protection of the environment despite the establishment of the Ministry of Environment (Ministry of Environment, 2015); (Ministry of Environment, 2014).

In addition, several by-laws and directives (detailed and procedural regulations) were enacted by the Council of Ministers such as: Regulation of nature protection, Regulation of environment protection from population in emergency cases, Regulation of water protection, Regulation of air protection, Regulation of sea environment and shores protection, Regulation of nature reserves and national parks, Regulations of management of harmful and hazardous substances, transport and handling, Regulation of management of solid wastes, Regulation or environmental impact assessment and Regulation of soil protection (Ministry of Environment, 2015).

The investigation of this study is limited to three ministries: Ministry of Environment, Ministry of Agriculture and Ministry of Health. 


\subsubsection{The Ministry of Health (MoH)}

In 1926 the Emirate of Jordan issued the first health law and established a department for health affairs. The Department became a Ministry in 1950. The latest of several amendments of the law was enacted in 2008 (The Ministry of Health, The Ministry of Health, 2015).

Articles in the General Health Law number 47 for year 2008 specify the responsibility of the Ministry in monitoring water purification, chemical materials, medical wastes, wastewater and wastewater treatment plants, smoking in public places and illegal disposal of wastes.

The law also specifies penalties associated with each type of violation. Penalties consist of a range of financial fines that increase according to the size of violation, imprisonment that varies depending on the seriousness of the violation and a combination of both fines and imprisonment which also varies with the type and number of repetitions of the violation.

\subsubsection{Ministry of Agriculture}

The Ministry of Agriculture was established in 1929. The agriculture law was subject to several amendments, the most recent being in 2002 (The Ministry of Agriculture, The Ministry of Agriculture, 2014).

The responsibilities of the Ministry of Agriculture (MoA) as clarified by Law no 44 for 2002 are the following:

- Organizing and monitoring the agricultural sector in order to maintain sustainable use of Jordan's agricultural resources, while preventing any harmful consequences to the environment.

- Safeguarding health of humans and animals from possible threats such as the use of additives, contaminants, toxic chemicals or bio-organisms that cause diseases.

- Safeguarding plant life, quality of soil and water.

- Combatting animal and plant pests and diseases, immunizing animals against epidemic diseases and carrying out laboratory analyses and field tests related to agricultural production.

- Conserving bio-diversity, regulating and monitoring the hunting of wild birds and animals, protecting endangered species and controlling littering caused by agricultural activities.

- Implementing safe disposal of plastic materials and empty containers of seeds and insecticides.

- Verifying compliance of agricultural inputs and outputs with technical rules issued by the Ministry.

The law specifies measures of enforcement to monitor and detect violations of the rules and regulations and empowers the (MoA) to subject violators to the type of punishment specified in the law. The sequence of enforcement starts with banning, licensing, imposing specification, inspection, issuing warning notices, fines for moderate violations, confiscation of property, revoking of licenses, fines and imprisonment for serious or repeated violations. Monitoring includes imported goods on the borders, on roads, and onsite inspection.

\subsubsection{Ministry of Environment}

Although many issues of environmental concern were addressed by the laws and regulations of agencies named above, Jordan environmental policy has been formally adopted through the Environment Protection Law no. (1) in 2003 and creating the Ministry of Environment (MoE) (Ministry of Environment, 2015). The Environment law defines the following tasks for the ministry (Ministry of Environment, 2014):

- Developing public policy for the protection of the environment and preparing plans, programs and projects necessary to achieve sustainable development.

- Preparing specifications and standards for environmental elements and components.

- Monitoring and measuring environmental impacts on natural resources elements and components through scientific centres according to adopted criteria.

- Issuing necessary environmental instructions to protect the environment and regulating the establishment of agricultural, development, commercial, industrial, housing and mining projects and other services to comply with preconditions for licensing or renewal of licences.

- Monitoring and supervising public and private institutions and entities, including companies and projects to ensure compliance with environmental standard specifications and technical regulations.

- Establishing the foundations for the regulation of harmful substances and hazardous substances and for regulations for collecting, classifying, storing, transporting, destroying and disposing of hazardous substances. 
- Authorizing the establishment of nature reserves and national parks, and managing, monitoring and supervising the parks.

The MoE has adopted the following initiatives to achieve the above mentioned tasks: waste and chemicals management program, transformation towards a green economy, environmental regulations, monitoring and protection of environment elements programs, pollution prevention, climate change program, management of natural resources and land use program, protecting Ecosystems and environmental awareness program (Ministry of Environment, 2014).

The law specifies the penalties for each type of violation of the conditions, standards, criteria, and restrictions specified by the law. These penalties include fines and/or imprisonment and termination of the license.

\section{Methodology and Data Sources}

\subsection{Data Sources}

The study relies on two sources of data: first, enacted laws, regulations and annual reports of the Ministries of Environment, Health, and Agriculture. Second, a questionnaire developed for the purposes of this study to garner the attitudes and opinions of the respondents with respect to the outcome of the implementation of the environment policy. The study population consists of directors of all directorates in the ministries of Environment, Agriculture, and Health headquarters and in the 13 governorates of the country, because these ministries are involved directly in the formulation, adoption and implementation of environment protection regulations. The total number of directors is 182. To avoid the drawbacks of small samples, the questionnaire was distributed to the whole population because of its limited size: 171 of the questionnaires were returned and 156 were complete and used in the analysis. The number represents $89 \%$, which is acceptable to draw conclusions. The data obtained from both sources provides sufficient base to answer the research questions.

A pre-test of the survey was conducted to ensure there were no issues, such as sequencing or wording of questions, which were identified and subsequently corrected. The final product of the pre-testing and modification task was the production of a survey that was as user-friendly as possible.

Questions addressed by the survey focused on the following areas only:

- The effect of implementing environment policy regulations on air, noise, and forests.

- The effect of implementing environment policy regulations on water pollution and uses of waste water.

- The effect of implementing environment policy regulations on soil protection.

- The effect of implementing environment policy regulations on habitat and species protection.

\subsection{The Research Model}

The conclusion from the literature review shows that command and control instruments mostly implemented to bring industries and other sources of negative externalities to compliance are: banning, licensing, monitoring, inspection, administrative notes, fines, imprisonment, and finally shutting down facilities. Instruments of command and control named above have been adopted in environmental regulations in Jordan (Ministry of Environment, 2014), (The Ministry of Health, The Ministry of Health, 2015), (The Ministry of Agriculture, The Ministry of Agriculture, 2014). This study uses those instruments as independent variables to examine their influence on controlling negative externalities in Jordan as dependent variables.

\subsubsection{Model Specifications}

The main hypotheses of this study are as follows:

$\mathrm{HO}_{1}$ : Monitoring instruments do not have statistically significant relationships to controlling negative externalities at $\alpha . \leq 0.05$.

$\mathrm{HO}_{2}$ : Enforcement instruments do not have statistically significant relationships to controlling negative externalities at $\alpha . \leq 0.05$.

$\mathrm{H}_{3}$ : Government capacity does not have a statistically significant relationship to controlling negative externalities at $\alpha . \leq 0.05$.

$\mathrm{G0}_{4}$ : Power and corruption do not have a statistically significant relationship to controlling negative externalities at $\alpha . \leq 0.05$.

In other words:

$$
\mathrm{H}_{0}: \beta_{1}=\beta_{2}=\beta_{3}=\beta_{4}=0 \quad \text { at } \alpha . \leq 0.05
$$


Independent variables $\mathrm{x}_{\mathrm{i}}$ do not predict the dependent variable.

Ordinary Least Square (OLS) multiple regression procedure is employed with the following specification to measure the contribution of explanatory variables to variations in the dependent variables:

$$
Y_{i}=\alpha+X_{i}+\varepsilon_{i}
$$

Where: $\mathrm{Y}=$ is compliance to regulation, $\mathrm{X}_{\mathrm{i}}=$ the four independent variables: monitoring, enforcement, government capacity and power and corruption; $\alpha=$ intercept term; and $\varepsilon=$ error term with mean zero; $\varepsilon i=$ error term with mean zero.

The dependent variables $Y_{i}$ are:

DEPFOR: forest protection.

DEPAIR: control of air pollution.

DEPWAT: control of water and soil pollution.

DEPH: control of hunting.

The independent variables $X_{i}$ are:

AFOMON: forest protection monitoring instruments.

AFOENF: forest protection enforcement instruments.

AWATMO: water pollution control monitoring instruments.

AWATENF: water pollution control enforcement instruments.

AAIRM: air pollution control monitoring instruments.

AAIRENF: air pollution control enforcement instruments.

AHUENF: hunting control enforcement instruments.

AGOVC: government institutional capacity building.

AP\&C: control of power and corruption

The equation will be applied on data from three samples representing key officials in the Ministry of Environment, Ministry of Health and Ministry of Agriculture.

\section{Data Presentation, Analysis and Results}

The following tables present a sample of the efforts by the responsible ministries to monitor and deter adverse effects on the environment and the outcome of those efforts.

Table 1. Number and percentage of approved applications for new investment projects

\begin{tabular}{|c|c|c|c|c|}
\hline Year & $\begin{array}{l}\text { Total number of } \\
\text { applications }\end{array}$ & Approved & Rejected & $\%$ of Approved \\
\hline 2010 & 955 & 681 & 274 & 71 \\
\hline 2011 & 1090 & 819 & 271 & 75 \\
\hline 2012 & 1396 & 1108 & 297 & 79 \\
\hline 2013 & 1461 & 1135 & 326 & 77 \\
\hline 2014 & 1675 & 1224 & 451 & 73 \\
\hline
\end{tabular}

Source: Ministry of Environment.

Table 1 shows that the MoE rejected almost $30 \%$ of proposed projects in industrial, agriculture and services sectors for environmental considerations. The environment law requires new investment projects to acquire approval for the intended location as a preventive measure prior to obtaining the license. The data in the Table shows high percentage of approved projects, which suggest a lenient implementation of the directive. The following tables reveal an increase in pollution rates that support such suspicion. 
Table 2. Percentage of pollution from several sources as registered during 2011-2013

\begin{tabular}{lllll}
\hline Year & $\begin{array}{l}\text { Noise } \\
\text { above normal }\end{array}$ & $\begin{array}{l}\text { Total dust } \\
\text { normal }\end{array}$ & above normal & Below normal \\
\hline 2011 & 32 & 48 & 0 & 52 \\
2012 & 0 & & & \\
2013 & 45 & & & \\
\hline
\end{tabular}

Source: Ministry of Health.

Table 2 shows the results of monitoring activities by the $\mathrm{MoH}$ in three years. Noise pollution witnessed an increase above the normal level. Dust monitoring was terminated by the $\mathrm{MoH}$ because it has become the responsibility of MoE. But no data about this source is available from the MoE.

Table 3. Annual number of visits and inspection by the ministry of health

\begin{tabular}{lllllll}
\hline Activity & 2009 & 2010 & 2011 & 2012 & 2013 & Trend \\
\hline Regular lab analysis of water samples & 6244 & 3663 & 2660 & 2811 & 2212 & declining \\
Comprehensive lab analysis of water samples & 13 & 10 & 2 & 2 & 4 & declining \& insignificant \\
Specialized lab analysis of water samples & 708 & 558 & 477 & 463 & 432 & declining \\
Bacterial Lab analysis of water samples & 1355 & 1940 & 3085 & 2832 & 2927 & increasing \\
Chemical lab analysis of waste water samples & 1544 & 1781 & 1748 & 1863 & 1866 & increasing \\
Chemical lab analysis of mineral water samples & - & 148 & 176 & 257 & - & terminated \\
Chemical lab analysis of water samples & 8798 & 5326 & 3895 & & & terminated \\
Measurement of air pollution & 85 & 31 & - & - & - & terminated \\
Inspection \& samples analysis from chemical factories & 87 & 131 & 102 & 128 & 88 & limited \\
Review of imported chemicals documents & 7481 & 9031 & 9436 & 10569 & 10890 & increasing \\
Review of imported mineral water documents & 442 & 389 & 276 & 203 & 257 & declining \\
Multi purposes visits and inspection & 1489 & 2455 & 2934 & 357 & 952 & declining \\
Inspection of dumping areas & 2 & 3 & 2 & - & 2 & few and insignificant \\
Inspection of waste water treatment plants & 64 & 63 & 42 & 49 & 53 & declining \\
Inspection of solid waste dumping areas & 10 & 29 & 40 & 5 & - & terminated \\
Inspection of chicken farms and slaughter houses & 2 & 10 & - & 2 & 3 & limited \\
Inspection of ice factories & 22 & 12 & 16 & 20 & 20 & few and insignificant \\
Inspection of water laboratories & 28 & 24 & 23 & 27 & 40 & few and insignificant \\
Measurement of noise & 3 & 27 & 29 & 6 & 4 & limited \\
\hline
\end{tabular}

Source: Annual Report 2014, Ministry of Health.

Table 3 reveals that inspection procedures for many activities were terminated because it has become the responsibility of the MoE. At the same time, the number of inspections of other activities was decreasing due to budget constraints, except the review of imported chemicals, which is increasing for security motives especially in recent years.

Table 4. Number of inspection visits to factories by the ministry of health

\begin{tabular}{lllllll}
\hline Activity & 2009 & 2010 & 2011 & 2012 & 2013 & Trend \\
\hline Primary inspection visits & 53 & 110 & 900 & 929 & 1723 & increasing \\
Follow up inspection visits & 468 & 508 & 1386 & 6332 & 7537 & increasing \\
Multi-party inspection visits & 115 & 114 & 794 & 1868 & 2554 & increasing \\
Inspection and taking samples & 93 & 39 & 337 & 221 & 182 & decreasing
\end{tabular}

Source: Annual Report 2014, Ministry of Health.

Table 4 demonstrates an increasing trend in the number of inspections of factories, which might be interpreted as a sign of increasing interest in protecting the environment. But since the data in the Table are in absolute numbers 
they do not reflect changes in percentage due to natural increase in number of factories and threats to the environment.

Table 5. Annual allocation of resources for the forest department

\begin{tabular}{llll}
\hline Years & Annual budget in \$US & No. of vehicles & No. of forest inspector patrols \\
\hline 2009 & 7.7 & 40 & 40 \\
2010 & 9.8 & 38 & 38 \\
2011 & 10.1 & 35 & 35 \\
2012 & 11.9 & 40 & 40 \\
2013 & 11.5 & 42 & 42 \\
\hline
\end{tabular}

Source: Forest Department/ Ministry of Agriculture.

Table 5 shows that available resources to the Department were almost constant despite the growth in responsibilities, especially with threats, because forests have become increasingly an alternative source of energy for heating and cooking attributed to increases in oil prices. The apparent increase in funds represents annual natural growth in salaries because both No of Vehicles and Inspector Patrols are constant.

Table 6. Number of inspection and deterrence methods performed by environment police patrol department: 2012-2014

\begin{tabular}{lllll}
\hline Type of activity & 2012 & 2013 & 2014 & Trend \\
\hline Inspection & 346 & 257 & 300 & constant \\
Sending notice (Warning) & 146 & 41 & 29 & decreasing \\
Shutting down the firm & 49 & 11 & 15 & decreasing \\
\hline
\end{tabular}

Source: Environment Police Department.

Table 6 demonstrates annual cases of inspection and enforcement during 2012-2014. It is clear that in general, efforts are declining under the pressure of financial constraints.

Table 7. Number of detected cases of cutting and transporting trees from the forests

\begin{tabular}{lllll}
\hline Years & 2012 & 2013 & 2014 & Trend \\
\hline No. of cases & 138 & 136 & 142 & Constant \\
\hline
\end{tabular}

Source: Environment Police Department.

Table 7 reports data on monitoring efforts by the Environmental Police Department. The figures reflect constant results despite the recognized increase in threats to the forests in Jordan. Data indicate that the government is avoiding pursuing illegal loggers more aggressively to avoid confrontation with the local populations, whom are largely dissatisfied with fuel prices set by the government (Dama, 2012); (Gerasa News, 2015).

Table 8. Number of cases of unlawful logging of trees seen by courts and percentage of sentences

\begin{tabular}{|c|c|c|c|c|}
\hline Years & $\begin{array}{l}\text { No. of violations seen by } \\
\text { the courts }\end{array}$ & $\begin{array}{l}\text { No. of verdicts of imprisonment } \\
\text { and/or financial penalties }\end{array}$ & $\%$ & Trend \\
\hline 2009 & 819 & 730 & 89 & almost constant \\
\hline 2010 & 480 & 344 & 72 & \\
\hline 2011 & 842 & 702 & 83 & \\
\hline 2012 & 1040 & 890 & 85 & \\
\hline 2013 & 1049 & 860 & 82 & \\
\hline
\end{tabular}

Source: Forest Department/Ministry of Agriculture.

Table 8 presents data on the deterrence activities by the Forest Department in the MoAg. The data shows that more 
than $80 \%$ of cases presented to courts by the Department received guilty verdicts, and sentences of either financial or imprisonment penalties. It should be noted that only very well documented cases can be sent to courts, otherwise the case can be dismissed. In addition, a high percentage of detected cases are usually settled under illegal exertion of influence (corruption), or substituted by warnings. The severity of verdicts is unknown to the Forest Department because once the case is sent to the court it becomes within the court's jurisdiction. Paid financial penalties are usually transmitted directly to the Ministry of Finance without notice to the Department of Forests, at least for follow up.

Table 9. Number of detected and confiscated vehicles loaded with untreated organic fertilizers

\begin{tabular}{lllllll}
\hline Year & 2010 & 2011 & 2012 & 2013 & 2014 & Trend \\
\hline Number of vehicles & 186 & 271 & 376 & 221 & 145 & decreasing \\
Quantity in tons & 836 & 1670 & 2767 & 2306 & 1182 & increasing \\
\hline
\end{tabular}

Source: Environment Police Department.

Table 9 shows an almost $50 \%$ decline in number of detected vehicles loaded with untreated animal source fertilizers. The data indicates some sort of relaxation by the government which may be attributable to internal security considerations, an ever-increasing budget deficit in addition to corruption.

Table 10. Number of visits, detected violations, penalties performed in madaba governorate in 2014

\begin{tabular}{|c|c|c|c|c|c|c|}
\hline Years & $\begin{array}{l}\text { No. of routine } \\
\text { visits }\end{array}$ & $\begin{array}{l}\text { No. of surprised } \\
\text { visits }\end{array}$ & $\begin{array}{l}\text { No. of first time } \\
\text { violations }\end{array}$ & $\begin{array}{l}\text { No. of repeated } \\
\text { violations }\end{array}$ & $\begin{array}{l}\text { No. of } \\
\text { closing }\end{array}$ & $\begin{array}{l}\text { No. of financial } \\
\text { penalties }\end{array}$ \\
\hline 2010 & 4628 & 125 & 184 & 15 & 9 & 75 \\
\hline 2011 & 4717 & 177 & 86 & 35 & 5 & 64 \\
\hline 2012 & 5369 & 225 & 193 & 47 & 35 & 82 \\
\hline 2013 & 6085 & 221 & 189 & 28 & 19 & 76 \\
\hline 2014 & 8566 & 255 & 272 & 45 & 30 & 110 \\
\hline
\end{tabular}

Source: Health Department in Madaba Governorate.

Table 10 reveals that number of violations was increasing during the last five years despite the active role of the Department. The Table shows also that the burden on the Department was increasing annually which required allocating more resources. If the annual number of routine visits is divided by 12 months, the number of visits per month was between 300 and 500. Therefore, the average number of visits to each firm is almost once bi-monthly. There is no available data on number of imprisonments. The figures given in the table confirm the findings that the command and control approach is costly.

Table 11. Estimations of $\mathrm{CO}_{2}$ emissions of the energy sector: air compliance results summary, 2000-2010

\begin{tabular}{lll}
\hline $\begin{array}{l}\text { Year } \\
2001\end{array}$ & $\begin{array}{l}1000(\text { ton }) \mathrm{C}_{2} \\
15.03\end{array}$ & $\begin{array}{l}\text { Trend } \\
\text { Emissions of year 2010/Emissions of year 2001: } \\
20.38 / 15.03=1.39\end{array}$ \\
2002 & 15.755 & \\
2003 & 16.671 & \\
2004 & 18.6 & \\
2005 & 20.293 \\
2006 & 20.26 \\
2007 & 20691 & \\
2008 & 19.83 \\
2009 & 20.806 \\
2010 & 20.381 & \\
\hline
\end{tabular}

Source: Jordan's third national communication on climate change submitted to the UN framework convention, 2014.

Table 11 shows an upward trend of $\mathrm{CO}_{2}$ emissions from the energy sector. Emissions increased by $39 \%$ in five 
years. The data reflects weak compliance to air quality standards regulations.

Table 12. Overall GHG emission for Jordan $(\mathrm{Gg})$

\begin{tabular}{llllllll}
\hline Years & PE & IP & WASTE & LULUCF & Agriculture & Net for all sectors & $\begin{array}{l}\text { Change from year to } \\
\text { year }\end{array}$ \\
\hline 2007 & 19998 & 1984 & 3190 & 868 & 1314 & 27354 & $100 \%$ \\
2008 & 19478 & 2124 & 2889 & 869 & 1325 & 26685 & $-2.5 \%$ \\
2009 & 20119 & 1804 & 2952 & 854 & 1338 & 27068 & $+14 \%$ \\
2010 & 19990 & 1365 & 3017 & 853 & 1352 & 26577 & $-2 \%$ \\
2011 & 21181 & 1808 & 3089 & 851 & 1365 & 28294 & $+6 \%$ \\
2012 & 24272 & 1671 & 3162 & 1213 & 1386 & 31703 & $+20 \%$ \\
2013 & 26424 & 1858 & 3237 & 1209 & 1407 & 34138 & $+7 \%$ \\
2014 & 25961 & 1943 & 3296 & 1204 & 1428 & 33832 & $-1 \%$ \\
& & & & & & & $+24 \%$ \\
\hline
\end{tabular}

Source: From Table A. 23 Jordan's third national communication on climate change 2014.

Table 12 reports that net greenhouse gases (GHG) emissions were increasing during the period (with marginal fluctuations). The net change was $24 \%$ at the end of the period in comparison with the base year 2007. The data reveals ineffective deterrence and weak compliance by sources of emissions.

Table 13. GHG emissions of the baseline scenario for the waste sector

\begin{tabular}{llll}
\hline Years & $\mathrm{CH}_{4}$ emissions from domestic landfills & $\mathrm{N}_{2} \mathrm{O}$ & $\left(\mathrm{Gg} \mathrm{CO}_{2} \mathrm{eq}\right)$ \\
\hline 2010 & 2876 & 141 & 3017 \\
2015 & 3140 & 161 & 3301 \\
\hline
\end{tabular}

Source: From Table 3.2. Jordan's third national communication on climate change 2014.

Table 13 demonstrates an increase by $9 \%$ in $\mathrm{CH}_{4}$ emissions from domestic landfills, $14 \%$ in $\mathrm{N} 2 \mathrm{O}$ emissions, and $9 \%$ in (Gg CO2eq) during the years 2010-2015. The data demonstrates ineffective impact of regulations on compliance.

Table 14. GHG emission for the industrial processes

\begin{tabular}{lllllll}
\hline Years & $\mathrm{N}_{2} \mathrm{O}$ & Trend & $\mathrm{CO}_{2}$ & Trend & $\mathrm{CO}_{2} \mathrm{eq}(\mathrm{Gg})$ & Trend \\
\hline 2010 & 0.49 & & 1214 & & 1365 & $+46 \%$ \\
2015 & 0.59 & $+20 \%$ & 1816 & $+50 \%$ & 1998 & +8 \\
\hline
\end{tabular}

Source: from Table 3.3 Jordan's third national communication on climate change.

The data in Table 14 show a 20\%, 49.5\%, and 46\% increase in $\mathrm{N}_{2} \mathrm{O}, \mathrm{CO}_{2}, \mathrm{CO}_{2}$ eq emissions in five years. The Table also illustrates that the industrial sector is the third contributor to GHG emissions in Jordan. The main contributors to the industrial process emissions are the cement industry, lime, limestone, soda ash and nitric acid manufacturing industries. Data in the table constitutes further evidence of the ineffectiveness of the MoE in changing the behaviour of firms producing different types of air pollution. 
Table 15. The Mean, mode and median of average responses for policy outcomes

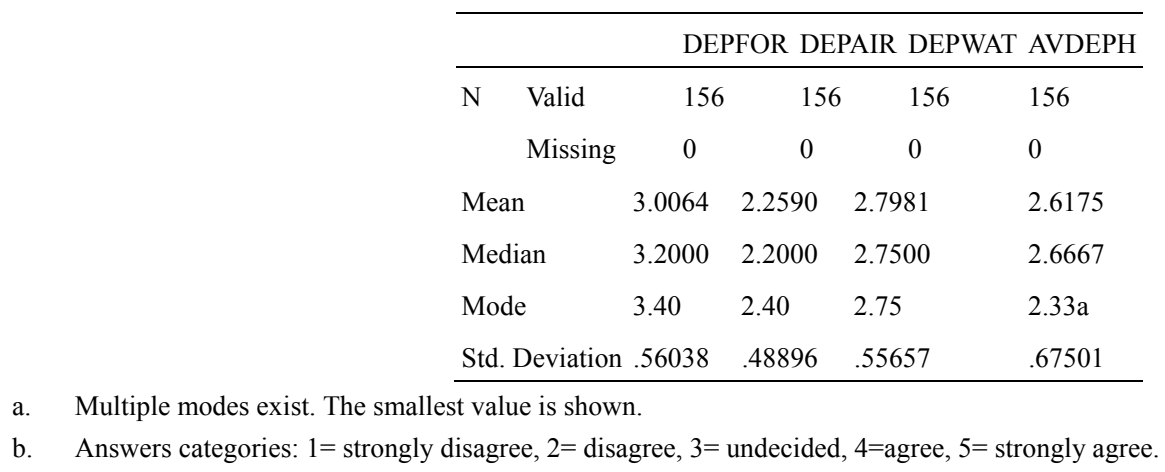

Table 15 presents the mean, mode, median and standard deviation of respondents' average answers. They represent respondents' opinion of the outcome of policy implementation by the three ministries. The Table shows that the mean and mode for controlling air pollution, water pollution and hunting fall in the disagree category. Taking standard deviation values into our account, the upper bound of the range becomes in the 'undecided'.

We conclude that most respondents do not agree that the environment policy achieved its goals of controlling air pollution, water pollution and hunting. In contrast, the mean, mode and median values of forest protection are above 3; therefore they fall in the undecided category. We conclude that overall, most of the respondents disagree that the ministries succeeded in controlling negative externalities.

Table 16. The mean, mode and median and standard deviation of the averages of independent variables

\begin{tabular}{|c|c|c|c|c|c|c|c|c|c|c|}
\hline & & AFOMON & AFOENF & AWATMO & AWATENF & AAIRM & AAIRENF & AHUENF & AGOVC & AP\&C \\
\hline \multirow[t]{2}{*}{$\mathrm{N}$} & Valid & 156 & 156 & 156 & 156 & 156 & 156 & 156 & 156 & 156 \\
\hline & Missing & 0 & 0 & 0 & 0 & 0 & 0 & 0 & 0 & 0 \\
\hline \multicolumn{2}{|c|}{ Mean } & 3.7196 & 3.2596 & 2.9979 & 2.8387 & 3.2141 & 2.9103 & 2.817 & 2.8154 & 3.3494 \\
\hline \multicolumn{2}{|c|}{ Median } & 3.7500 & 3.2500 & 3.0000 & 2.8333 & 3.2000 & 3.0000 & 3.00 & 2.8000 & 3.5000 \\
\hline \multicolumn{2}{|c|}{ Mode } & 3.75 & 3.00 & 3.00 & 2.92 & 3.00 & 3.20 & 2.5 & 2.80 & 3.50 \\
\hline \multicolumn{2}{|c|}{ Std. Deviation } & .49542 & .59153 & .44278 & .32096 & .67245 & .48582 & .789 & .48595 & .64488 \\
\hline
\end{tabular}

Answer categories: $1=$ strongly disagree, $2=$ disagree, $3=$ not decided, $4=$ agree, $5=$ strongly agree.

Table 16 presents the mean, mode, median and standard deviation of the averages of respondents' answers. They represent their opinions of the implementation of monitoring and enforcement instruments specified by the regulations. The second column of the Table shows the mean and mode for monitoring forest protection. Both values fall in the upper of 'undecided'. Adding the standard deviation value, the upper of the range becomes in the agree category while the lower of the range remains in undecided. In general, the upper value suggests that respondents consider implementation of monitoring instruments relatively effective.

The means and modes for the third, fourth, sixth, seventh and tenth columns are inconclusive, while the values of the mean and mode for the fifth, eighth and ninth columns fall in the 'disagree' category with almost 0.05 standard deviation. We conclude from the mean and mode values that respondents do not consider the implementation of monitoring and enforcement instrument as effective. The values of mean and mode for government institutional capacity fall in the disagree category but very close to undecided.

Taking the value of standard deviation into calculation, we conclude that respondents do not consider government institutional capacity appropriate to perform effective monitoring and enforcement. Finally, the values of the mean and mode for the influence of power and corruption on the implementation of environmental regulations fall in the middle of the range between undecided and agree. Adding the standard deviation value, the upper of the range values becomes in the agree category.

We conclude that respondents consider power and corruption an obstacle in the implementation process of monitoring and enforcement regulations. In general, the results are inconclusive. There is no significant support 
to either direction: agree or disagree that environment policy in Jordan is effective.

Table 17. Model summary, ANOVA, coefficients ${ }^{\mathrm{a}, \mathrm{b}}$

\begin{tabular}{|c|c|c|c|c|c|c|c|}
\hline \multirow[b]{2}{*}{ Model 1} & \multicolumn{2}{|c|}{ Unstandardized Coefficients } & \multirow{2}{*}{$\begin{array}{l}\text { Standardized } \\
\text { Coefficients } \\
\text { Beta }\end{array}$} & \multirow[b]{2}{*}{$\mathrm{t}$} & \multirow[b]{2}{*}{ Sig. } & \multicolumn{2}{|c|}{ Collinearity Statistics } \\
\hline & B & Std. Error & & & & Tolerance & VIF \\
\hline (Constant) & 3.190 & 2.608 & & 1.223 & .241 & & \\
\hline AVFMON & .535 & .390 & .326 & 1.371 & .192 & .886 & 1.129 \\
\hline AVFENF & $-.172-$ & .285 & $-.144-$ & $-.604-$ & .555 & .883 & 1.133 \\
\hline AGOVC & $-.691-$ & .386 & $-.402-$ & $-1.791-$ & .095 & .997 & 1.003 \\
\hline AVPOC & .005 & .304 & .004 & .015 & .988 & .852 & 1.174 \\
\hline \multirow[t]{2}{*}{ Model Summary } & $\mathrm{R}$ & R Square & \multicolumn{5}{|l|}{ Adjusted R Square } \\
\hline & .546 & .298 & .097 & & $\mathrm{DF}$ & Durbin-Wa & tistic \\
\hline \multirow[t]{2}{*}{ ANOVA $^{\mathbf{b}, \mathbf{c}}$} & $\mathrm{F}$ & Sig. & & & 18 & 1.227 & \\
\hline & 1.486 & $.259^{\mathrm{a}}$ & & & & & \\
\hline
\end{tabular}

a. Predictors: (Constant), AVpoC, Avegovc, AVFMON, AVFENF.

b. Dependent Variable: DEPFOR.

c. Unless noted otherwise, statistics are based only on cases for which Ministry = Ministry of Environment.

Table 17 reports regression results of the impact of monitoring and enforcement instruments, government institutional capacity and corruption and power on achieving the environment policy in Jordan of reducing threats to forests as a negative externality. The results correspond to the responses of a sample from the Ministry of Environment. R value indicates a positive and moderate association between the predictors and the dependent variable. The four predictors in the model produced $\mathrm{R}^{2}=.298$ which is positive but insignificant at both 0.05 and 0.1 levels. The values of the $t$ test for the coefficients are also insignificant except for government institutional capacity which is statistically significant at 0.1 level. Both Tolerance and VIF values suggest absence of collinearity. Values of the variance inflation factor of the linear regression (VIF) in the table are $<10$, an indication of non-multicollinearity.

The observed value of Durbin-Watson Statistics in Table $17(1,227)$ is between the tabulated lower and upper bound of the range, therefore, the test is inconclusive and we would not reject the null hypothesis of none-autocorrelated errors. The plot of residual errors shows that they are normally distributed. They fall in a symmetrical pattern and have a constant spread throughout the range and centered on zero throughout the range of fitted values.

Table 18. Model summary, ANOVA, coefficients ${ }^{\mathrm{a}, \mathrm{b}}$

\begin{tabular}{|c|c|c|c|c|c|c|c|}
\hline \multirow[b]{2}{*}{ Model 1} & \multicolumn{2}{|c|}{ Unstandardized Coefficients } & \multirow{2}{*}{$\begin{array}{l}\text { Standardized Coefficients } \\
\text { Beta }\end{array}$} & \multirow[b]{2}{*}{$\mathrm{t}$} & \multirow[b]{2}{*}{ Sig. } & \multicolumn{2}{|c|}{ Collinearity Statistics } \\
\hline & $\mathrm{B}$ & Std. Error & & & & Tolerance & VIF \\
\hline (Constant) & 3.059 & .747 & & 4.097 & .000 & & \\
\hline AVFMON & $-.057-$ & .124 & $-.055-$ & $-.458-$ & .649 & .945 & 1.058 \\
\hline AVFENF & .124 & .090 & .169 & 1.387 & .170 & .937 & 1.067 \\
\hline AVEGOVC & $-.218-$ & .122 & $-.221-$ & $-1.788-$ & .079 & .909 & 1.101 \\
\hline AVPOC & .138 & .089 & .185 & 1.558 & .124 & .983 & 1.017 \\
\hline \multirow[t]{2}{*}{ Model Summary } & $\mathrm{R}$ & R Square & Adjusted R Square & & & & \\
\hline & $.357^{\mathrm{a}}$ & .128 & .072 & & $\mathrm{DF}$ & Durbin-W & atistic \\
\hline \multirow[t]{2}{*}{$\mathrm{ANOVA}^{\mathrm{b}, \mathrm{c}}$} & $\mathrm{F}$ & Sig. & & & 67 & 1.999 & \\
\hline & 2.305 & $.068^{\mathrm{a}}$ & & & & & \\
\hline
\end{tabular}

a. Predictors: (Constant), AVpoC, Avegove, AVFMON, AVFENF.

b. Dependent Variable: DEPFOR.

c. Selecting only cases for which Ministry $=$ Ministry of Agriculture. 
Table 18 reports regression results of the analysis of the data from the Ministry of Agriculture sample. $\mathrm{R}$ value (.357) indicates a positive and moderate association between the predictors and the dependent variable. The four predictors of the model produced $\mathrm{R} 2=.128$ which is positive and significant at 0.1 levels, $\mathrm{P}=.068<0.1$.

The results suggest that the predictors explain $13 \%$ of the variation in the dependent variable. The values of a $t$ test for the coefficients are insignificant except for government institutional capacity which is statistically significant at 0.1 level $p=0.079<0.1$. VIF statistics are $<10$ an indication of non-multicollinearity. Tolerance statistics value supports this conclusion. The observed test statistic value of Durbin-Watson Statistics $=(1,999)>$ than the tabulated upper bound, therefore, we would not reject the null hypothesis of non-autocorrelated errors.

Hence, combining the results from both Table 17 and Table 18 indicates that the joint influence of the four predictors: monitoring, enforcement, government institutional capacity and corruption and power on the elimination of threats to forests in Jordan as a negative externality is very low. Only government capacity building is significant among the four predictors.

What can be inferred from such result that both Ministries: Ministry of Agriculture and Ministry of Environment are ineffective in achieving the aim of the environment policy in Jordan of reducing threats to forests as a negative externality.

Table 19. Model summary, ANOVA, coefficients ${ }^{\mathrm{a}}$

\begin{tabular}{|c|c|c|c|c|c|c|c|}
\hline \multirow[b]{2}{*}{ Model 1} & \multicolumn{2}{|c|}{ Unstandardized Coefficients } & \multirow{2}{*}{$\begin{array}{l}\text { Standardized Coefficients } \\
\text { Beta }\end{array}$} & \multirow[b]{2}{*}{$\mathrm{t}$} & \multirow[b]{2}{*}{ Sig. } & \multicolumn{2}{|c|}{ Collinearity Statistics } \\
\hline & $\mathrm{B}$ & Std. Error & & & & Tolerance & VIF \\
\hline (Constant) & 2.997 & 1.723 & & 1.740 & .104 & & \\
\hline Avegovc & .234 & .260 & .212 & .898 & .384 & .844 & 1.185 \\
\hline AVPOC & .142 & .180 & .177 & .792 & .442 & .939 & 1.065 \\
\hline AVAIRM & .055 & .235 & .054 & .232 & .820 & .879 & 1.138 \\
\hline AVAIRENF & $-.681-$ & .309 & $-.505-$ & $-2.207-$ & .044 & .898 & 1.114 \\
\hline \multirow[t]{2}{*}{ MODEL SUMMARY } & $\mathrm{R}$ & R Square & Adjusted R Square & & & & \\
\hline & $.585^{\mathrm{a}}$ & .343 & .155 & & $\mathrm{DF}$ & Durbin-Wa & son Statistic \\
\hline \multirow[t]{2}{*}{ ANOVA $^{\mathrm{b}, \mathrm{c}}$} & $\mathrm{F}$ & Sig. & & & 18 & 2.099 & \\
\hline & 1.824 & $.180^{\mathrm{a}}$ & & & & & \\
\hline
\end{tabular}

Table 19 reports regression results of the analysis of the data from the Ministry of Environment sample. The results show a moderate positive association between the predictors and the predicted variable. The $\mathrm{R}^{2}$ value is positive but insignificant at 0.05 or 0.1 levels, $\mathrm{P}=0.18$ which suggests that there is no causal relationship between the model and the variations in the data.

The values of a $t$ test for the coefficients are insignificant except the coefficient of enforcement which is statistically significant at 0.05 level $p=0.044<0.05$. VIF statistics are $<10$ an indication of non multicollinearity, the same indication from Tolerance test.

The observed test statistic value of Durbin-Watson Statistics $=(2.099)>$ than the tabulated upper bound, therefore, we would not reject the null hypothesis of non-autocorrelated errors. We can conclude from the results that, in general, the Ministry of Environment is relatively ineffective in achieving the goal of the environment law of controlling air pollution as a negative externality. However enforcement instruments that are the responsibility of several organizations, among them the Ministry of Environment, is relatively effective. 
Table 20. Model Summary, Anova, Coefficients ${ }^{\mathrm{a}, \mathrm{b}}$

\begin{tabular}{|c|c|c|c|c|c|c|c|}
\hline \multirow[b]{2}{*}{ Model 1} & \multicolumn{2}{|c|}{ Unstandardized Coefficients } & \multirow{2}{*}{$\begin{array}{l}\text { Standardized Coefficients } \\
\text { Beta }\end{array}$} & \multirow[b]{2}{*}{$\mathrm{t}$} & \multirow[b]{2}{*}{ Sig. } & \multicolumn{2}{|c|}{ Collinearity Statistics } \\
\hline & $\mathrm{B}$ & Std. Error & & & & Tolerance & VIF \\
\hline (Constant) & 2.255 & .615 & & 3.666 & .001 & & \\
\hline AVEGOVC & $-.160-$ & .109 & $-.172-$ & $-1.475-$ & .145 & .965 & 1.036 \\
\hline AVPOC & $-.144-$ & .085 & $-.197-$ & $-1.703-$ & .093 & .981 & 1.020 \\
\hline AVAIRM & .194 & .085 & .269 & 2.298 & .025 & .956 & 1.047 \\
\hline AVAIRENF & .116 & .109 & .123 & 1.067 & .290 & .990 & 1.010 \\
\hline \multirow[t]{2}{*}{ Model Summary } & $\mathrm{R}$ & R Square & Adjusted R Square & & & & \\
\hline & $.400^{\mathrm{a}}$ & .160 & .107 & & $\mathrm{DF}$ & Durbin-Wa & son Statistic \\
\hline \multirow[t]{2}{*}{ ANOVA $^{\mathbf{b , c}}$} & $\mathrm{F}$ & Sig. & & & 68 & 1.919 & \\
\hline & 3.040 & $.023^{\mathrm{a}}$ & & & & & \\
\hline
\end{tabular}

Table 20 reports regression results of the analysis of the data from the Ministry of Health. The results provide evidence of a moderate positive correlation between the predictors and reducing levels of air pollution as a dependent variable. As can be seen in the Table, $\mathrm{R}^{2}$ value is positive and significant at 0.05 levels, $\mathrm{P}=.023<0.05$. $R^{2}$ suggests that the joint influence of the predictors of the model explain $40 \%$ of the variations in the data.

The values of a $t$ test for the coefficients reveals that two independent variables are significant. The first one is that power and corruption significant at 0.1 as $\mathrm{p}=.093<0.1$. The second is monitoring significant at 0.05 as $\mathrm{p}=$ $0.025<0.05$. Tests for multicollinearity suggest non-multicollinearity based on values of VIF statistics are $<10$. Tolerance statistics value supports such conclusion. The observed test statistic value of Durbin-Watson Statistics $=(1.919)>$ than the tabulated upper bound, therefore, we would not reject the null hypothesis of non-autocorrelated errors. We can conclude from the results that in general the Ministry of Health is effective in achieving the goal of the environment law of controlling air pollution as a negative externality. It is worth mentioning that the influence of both variables power and corruption and monitoring is significant in achieving the environment policy of controlling air pollution.

Table 21. Model summary, ANOVA, coefficients ${ }^{\mathrm{a}, \mathrm{b}}$

\begin{tabular}{|c|c|c|c|c|c|c|c|}
\hline \multirow[b]{2}{*}{ Model 1} & \multicolumn{2}{|c|}{$\begin{array}{l}\text { Unstandardized } \\
\text { Coefficients }\end{array}$} & \multirow{2}{*}{$\begin{array}{l}\text { Standardized } \\
\text { Coefficients } \\
\text { Beta }\end{array}$} & \multirow[b]{2}{*}{$\mathrm{t}$} & \multirow[b]{2}{*}{ Sig. } & \multicolumn{2}{|c|}{ Collinearity Statistics } \\
\hline & $\mathrm{B}$ & Std. Error & & & & Tolerance & VIF \\
\hline (Constant) & 1.987 & .689 & & 2.884 & .005 & & \\
\hline AVEGOVC & .312 & .126 & .294 & 2.466 & .016 & .987 & 1.013 \\
\hline AVPOC & $-.044-$ & .098 & $-.055-$ & $-.450-$ & .654 & .940 & 1.064 \\
\hline AVAIRM & $-.064-$ & .082 & $-.094-$ & $-.778-$ & .439 & .967 & 1.034 \\
\hline AVAIRENF & $-.090-$ & .122 & $-.090-$ & $-.741-$ & .461 & .958 & 1.044 \\
\hline Model & $\mathrm{R}$ & R Square & Adjusted R Square & & & & \\
\hline summary & $.337^{\mathrm{a}}$ & .113 & .057 & & $\mathrm{DF}$ & \multicolumn{2}{|c|}{ Durbin-Watson Statistic } \\
\hline \multirow[t]{2}{*}{ ANOVA $^{\mathbf{b , c}}$} & $\mathrm{F}$ & Sig. & & & 67 & 2.117 & \\
\hline & 2.013 & $.103^{\mathrm{a}}$ & & & & & \\
\hline
\end{tabular}

Table 21 reports regression results of the analysis of data from the Ministry of Agriculture. The results provide 
evidence of a moderate positive correlation between the predictors and reducing levels of air pollution as a dependent variable. As can be seen in the table, $\mathrm{R}^{2}$ value is positive and insignificant at both 0.05 and 0.1 levels. $\mathrm{P}=.103>0.05 . \mathrm{R}^{2}$ suggests that there is no causal relationship between the model and the variations in the data.

The values of a $t$ test for the coefficients reveal that none of the independent variables is significant at 0.05 . Statistical tests suggest non-multicollinearity based on values of VIF statistics are $<10$. Tolerance statistics value supports this conclusion.

The observed test statistic value of Durbin-Watson Statistics $=(2.117)>$ than the tabulated upper bound, therefore, we would not reject the null hypothesis of non-autocorrelated errors.

We can conclude from the results presented in Table 21 that in general the Ministry of Agriculture is ineffective in achieving the goal of the environment policy of controlling air pollution as a negative externality.

Hence, combining the results point to a low joint causal relationship between the model predictors and levels of air pollution in Jordan as a negative externality.

Table 22. Model summary, ANOVA, coefficients ${ }^{\mathrm{a}, \mathrm{b}}$

\begin{tabular}{|c|c|c|c|c|c|c|c|}
\hline \multirow{3}{*}{$\begin{array}{l}\text { Model } 1 \\
\text { (Constant) }\end{array}$} & \multicolumn{2}{|c|}{ Unstandardized Coefficients } & \multicolumn{3}{|l|}{ Standardized Coefficients } & \multicolumn{2}{|c|}{ Collinearity Statistics } \\
\hline & B & Std. Error & Beta & $\mathrm{t}$ & Sig. & Tolerance & VIF \\
\hline & 2.187 & 1.454 & & 1.504 & .153 & & \\
\hline AVEGOVC & $-.039-$ & .358 & $-.028-$ & $-.109-$ & .914 & .981 & 1.019 \\
\hline AVPOC & .123 & .263 & .122 & .469 & .645 & .965 & 1.036 \\
\hline AVHENF & .049 & .227 & .057 & .218 & .831 & .947 & 1.055 \\
\hline \multirow[t]{2}{*}{ Model Summary } & $\mathrm{R}$ & R Square & \multicolumn{5}{|l|}{ Adjusted R Square } \\
\hline & $.127^{\mathrm{a}}$ & .016 & $-.181-$ & & DF & Durbin-W & on Statistic \\
\hline \multirow[t]{2}{*}{ ANOVA $^{\mathbf{b}, \mathbf{c}}$} & $\mathrm{F}$ & Sig. & & & 18 & 2.143 & \\
\hline & .082 & $.969^{\mathrm{a}}$ & & & & & \\
\hline
\end{tabular}

a. Predictors: (Constant), AVHENF, AVEGOVC, AVPOC.

b. Dependent Variable: AVDEPHU.

c. Selecting only cases for which Ministry = Ministry of Environment.

Table 22 reports regression results of the analysis of the data from the Ministry of Environment. The results provide evidence of positive but low correlation between the predictors and reducing the threats of hunting as a dependent variable. Also, $\mathrm{R}^{2}$ value is positive but very low and insignificant at 0.05 and 0.1 levels $\mathrm{P}=.969>$ 0.05 or $\mathrm{R}^{2}$ is not different from 0 since there is no significant causal relationship between the model and the variations in the data. The values of $t$ test for the coefficients reveal that all independent variables in the model are insignificant at 0.05 or 0.1 . Tests for multicollinearity suggest that the assumption of non multicollinearity holds based on values of VIF statistics are $<10$. Tolerance statistics value supports such conclusion.

The observed test statistic value of Durbin-Watson Statistics $=(2.143)>$ than the tabulated upper bound therefore, we would not reject the null hypothesis of non-autocorrelated errors.

We can conclude from the results presented in Table 22 that in general the Ministry of Environment is ineffective in achieving the goal of the environment policy of controlling hunting as a negative externality. 
Table 23. Model summary, ANOVA, coefficients

\begin{tabular}{|c|c|c|c|c|c|c|c|}
\hline \multirow[b]{2}{*}{ Model 1} & \multicolumn{2}{|c|}{ Unstandardized Coefficients } & \multirow{2}{*}{$\begin{array}{l}\text { Standardized Coefficients } \\
\text { Beta }\end{array}$} & \multirow[b]{2}{*}{$\mathrm{t}$} & \multirow[b]{2}{*}{ Sig. } & \multicolumn{2}{|c|}{ Collinearity Statistics } \\
\hline & $\mathrm{B}$ & Std. Error & & & & Tolerance & VIF \\
\hline (Constant) & 1.830 & .683 & & 2.679 & .009 & & \\
\hline AVEGOVC & .021 & .173 & .015 & .122 & .904 & .974 & 1.026 \\
\hline AVPOC & .147 & .130 & .140 & 1.135 & .260 & .998 & 1.002 \\
\hline AVHENF & .094 & .103 & .114 & .915 & .364 & .973 & 1.028 \\
\hline \multirow[t]{2}{*}{ MODEL SUMMARY } & $\mathrm{R}$ & R Square & Adjusted R Square & & & & \\
\hline & $.186^{\mathrm{a}}$ & .035 & $-.011-$ & & $\mathrm{DF}$ & Durbin-We & atistic \\
\hline \multirow[t]{2}{*}{ ANOVA $^{\mathrm{b}, \mathrm{c}}$} & $\mathrm{F}$ & Sig. & & & 67 & 2.128 & \\
\hline & .767 & $.517^{\mathrm{a}}$ & & & & & \\
\hline
\end{tabular}

a. Predictors: (Constant), AVHENF, AVPOC, Avegovc.

b. Dependent Variable: AVDEPH.

c. Selecting only cases for which Ministry $=$ Ministry of Agriculture.

Table 23 reports regression results of the analysis of the data from the Ministry of Agriculture. The results provide evidence of a low but positive correlation between the predictors and reducing the threats of hunting as a dependent variable. As can be seen in the Table, $\mathrm{R}^{2}$ value also is positive but very low and insignificant at both levels 0.05 and $0.1 . \mathrm{P}=.517>0.05 . \mathrm{R}^{2}$ suggests that there is no causal relationship between the model and the variations in the data and its value is not different from 0 .

The values of $t$ test for the coefficients reveal that all independent variables in the model are insignificant at 0.05 or 0.1 . Tests for multicollinearity suggest absence of multicollinearity based on values of VIF statistics are $<10$. $=$ Tolerance statistics value leads to the same conclusion.

The observed test statistic value of Durbin-Watson Statistics $=(2.128)>$ than the tabulated upper bound therefore, we would not reject the null hypothesis of non-autocorrelated errors.

We can conclude from the results presented in Table 23 that in general the Ministry of Agriculture is ineffective in achieving the goal of the environment policy of controlling hunting as a negative externality.

Hence, combining the results from both Tables 22 and 23 points to low joint causal relationship between the four predictors of the model; monitoring, enforcement, government institutional capacity and corruption and power on one side and controlling hunting in Jordan as a negative externality on the other.

Table 24. Model summary, ANOVA, coefficients ${ }^{\mathrm{a}, \mathrm{b}}$

\begin{tabular}{|c|c|c|c|c|c|c|c|}
\hline \multirow[b]{2}{*}{ Model 1} & \multicolumn{2}{|c|}{ Unstandardized Coefficients } & \multirow{2}{*}{$\begin{array}{l}\text { Standardized Coefficients } \\
\text { Beta }\end{array}$} & \multirow[b]{2}{*}{$\mathrm{t}$} & \multirow[b]{2}{*}{ Sig. } & \multicolumn{2}{|c|}{ Collinearity Statistics } \\
\hline & $\mathrm{B}$ & Std. Error & & & & Tolerance & VIF \\
\hline (Constant) & 2.742 & 2.082 & & 1.317 & .209 & & \\
\hline AVEGOVC & $-.308-$ & .312 & $-.263-$ & $-.985-$ & .341 & .885 & 1.130 \\
\hline AVPOC & .135 & .215 & .158 & .629 & .540 & .997 & 1.003 \\
\hline AVEWATMO & .409 & .435 & .257 & .942 & .362 & .845 & 1.183 \\
\hline AVWATENF & $-.169-$ & .578 & $-.077-$ & $-.293-$ & .774 & .909 & 1.100 \\
\hline \multirow[t]{2}{*}{ Model Summary } & $\mathrm{R}$ & R Square & Adjusted R Square & & & & \\
\hline & $.345^{\mathrm{a}}$ & .119 & $-.133-$ & & DF & Durbin-Wa & n Statistic \\
\hline \multirow[t]{2}{*}{$\mathrm{ANOVA}^{\mathbf{b , c}}$} & $\mathrm{F}$ & Sig. & & & 18 & 1.641 & \\
\hline & .471 & $.756^{\mathrm{a}}$ & & & & & \\
\hline
\end{tabular}

a. Predictors: (Constant), AVWATENF, AVPOC, AVEGOVC, AVEWATMO.

b. Dependent Variable: DEPWAT.

c. Selecting only cases for which Ministry = Ministry of Environment. 
Table 24 reports regression results of the analysis of the data from the Ministry of Environment. The results provide evidence of a moderate positive correlation between the predictors and reducing water and soil pollution as a dependent variable. As can be seen from the table, $\mathrm{R}^{2}$ value is positive but very low and insignificant at both levels 0.05 and 0.1. $\mathrm{P}=.756>0.05 . \mathrm{R}^{2}$ suggests that there is no causal relationship between the model and the variations in the data, or $\mathrm{R}^{2}=0$. The values of a t test for the coefficients reveal that all independent variables in the model are insignificant at 0.05 or 0.1 . This means that $\mathrm{b} 1=\mathrm{b} 2=\mathrm{b} 3=\mathrm{b} 4=0$. In other words, variations in water and soil pollution cannot be explained by variations in the independent variables: monitoring, enforcement, organizational capacity and power and corruption.

Tests for multicollinearity suggest non-multicollinearity based on values of VIF statistics are $<10$. Tolerance statistics value leads to the same conclusion. The observed value of the test statistic of Durbin-Watson Statistics in Table 1 (1.641) is between the tabulated lower and upper bounds, therefore, the test is inconclusive and we would not reject the null hypothesis of none-autocorrelated errors.

We can conclude from the results presented in Table 24 that in general the Ministry of Agriculture is ineffective in achieving the goal of the environment policy of controlling water and soil pollution as a negative externality.

Hence, combining the results from both tables 23 and 24 point to low combined causal relationship between the four predictors of the model; monitoring, enforcement, government institutional capacity and corruption and power on one side and the mitigating water and soil pollution in Jordan as a negative externality on the other.

Table 25. Model summary, ANOVA, coefficients ${ }^{\mathrm{a}, \mathrm{b}}$

\begin{tabular}{|c|c|c|c|c|c|c|c|}
\hline \multirow[b]{2}{*}{ Model 1} & \multicolumn{2}{|c|}{ Unstandardized Coefficients } & \multirow{2}{*}{$\begin{array}{l}\text { Standardized Coefficients } \\
\text { Beta }\end{array}$} & \multirow[b]{2}{*}{$\mathrm{t}$} & \multirow[b]{2}{*}{ Sig. } & \multicolumn{2}{|c|}{ Collinearity Statistics } \\
\hline & $\mathrm{B}$ & Std. Error & & & & Tolerance & VIF \\
\hline (Constant) & 3.156 & .862 & & 3.662 & .001 & & \\
\hline AVEGOVC & $-.115-$ & .130 & $-.108-$ & $-.880-$ & .382 & .999 & 1.001 \\
\hline AVPOC & .011 & .102 & .013 & .104 & .918 & .996 & 1.004 \\
\hline AVEWATMO & .138 & .158 & .108 & .870 & .387 & .975 & 1.026 \\
\hline AVWATENF & $-.178-$ & .213 & $-.104-$ & $-.835-$ & .407 & .973 & 1.028 \\
\hline \multirow[t]{2}{*}{ Model Summary } & $\mathrm{R}$ & R Square & Adjusted R Square & & & & \\
\hline & $.177^{\mathrm{a}}$ & .031 & $-.029-$ & & $\mathrm{DF}$ & Durbin-Wa & Statistic \\
\hline \multirow[t]{2}{*}{ ANOVA $^{\mathbf{b}, \mathbf{c}}$} & $\mathrm{F}$ & Sig. & & & 68 & 2.052 & \\
\hline & .517 & $.724^{\mathrm{a}}$ & & & & & \\
\hline
\end{tabular}

Table 25 reports regression results of the analysis of the data from the Ministry of Health. The results provide evidence of low positive correlation between the predictors and reducing water and soil pollution as a dependent variable. As can be seen from the table, $\mathrm{R}^{2}$ value is positive but very low and insignificant according to $\mathrm{F}$ test at both levels 0.05 and $0.1 . \mathrm{P}=.724>0.05 . \mathrm{R}^{2}$ suggests that there is no causal relationship between the model and the variations in the data, or $\mathrm{R}^{2}=0$.

The values of $t$ test for the coefficients reveal that all independent variables in the model are insignificant at both 0.05 and 0.1 levels. This means that $\mathrm{b} 1=\mathrm{b} 2=\mathrm{b} 3=\mathrm{b} 4=0$. In other words variations in water and soil pollution cannot be explained by variations in the independent variables: monitoring, enforcement, organizational capacity and power and corruption.

Tests for multicollinearity suggest non-multicollinearity based on values of VIF statistics are $<10$. Tolerance statistics value leads to the same conclusion.

The observed value of Durbin-Watson Statistics in 25 (2.052) is above the upper bound of the tabulated statistics. Therefore, the test is inconclusive and we would not reject the null hypothesis of none-autocorrelated errors.

We can conclude from the results presented in Table 25 that in general the Ministry of Health is ineffective in achieving the goal of the environment policy of controlling water and soil pollution as a negative externality. 
Table 26. Model summary, ANOVA, coefficients ${ }^{a, b}$

\begin{tabular}{|c|c|c|c|c|c|c|c|}
\hline \multirow[b]{2}{*}{ Model 1} & \multicolumn{2}{|c|}{ Unstandardized Coefficients } & \multirow{2}{*}{$\begin{array}{l}\text { Standardized Coefficients } \\
\text { Beta }\end{array}$} & \multirow[b]{2}{*}{$\mathrm{t}$} & \multirow[b]{2}{*}{ Sig. } & \multicolumn{2}{|c|}{ Collinearity Statistics } \\
\hline & $\mathrm{B}$ & Std. Error & & & & Tolerance & VIF \\
\hline (Constant) & 4.163 & .989 & & 4.208 & .000 & & \\
\hline AVEGOVC & $-.115-$ & .151 & $-.095-$ & $-.762-$ & .449 & .955 & 1.047 \\
\hline AVPOC & $-.236-$ & .115 & $-.257-$ & $-2.058-$ & .044 & .947 & 1.056 \\
\hline AVEWATMO & .039 & .148 & .033 & .262 & .794 & .942 & 1.062 \\
\hline AVWATENF & $-.135-$ & .206 & $-.082-$ & $-.656-$ & .514 & .948 & 1.055 \\
\hline \multirow[t]{2}{*}{ Model Summary } & $\mathrm{R}$ & R Square & Adjusted R Square & & & & \\
\hline & $.269^{\mathrm{a}}$ & .072 & .013 & & $\mathrm{DF}$ & Durbin-Wa & son Statistic \\
\hline \multirow[t]{2}{*}{ ANOVA $^{\mathbf{b , c}}$} & $\mathrm{F}$ & Sig. & & & 67 & 2.357 & \\
\hline & 1.228 & $.308^{\mathrm{a}}$ & & & & & \\
\hline
\end{tabular}

a. Predictors: (Constant), AVWATENF, AVEWATMO, Avegove, AVpoC.

b. Unless noted otherwise, statistics are based only on cases for which Ministry = Ministry of Agriculture.

c. Dependent Variable: DEPWAT.

Table 26 reports regression results of the analysis of the data from the Ministry of Agriculture. The results provide evidence of a low positive association between the predictors and water and soil pollution as a dependent variable. As can be seen from the table, $\mathrm{R}^{2}$ value is positive but very low and insignificant at both levels 0.05 and $0.1 . \mathrm{P}=.308>0.05$. $\mathrm{R}^{2}$ suggests that there is no causal relationship between the model and the variations in the data, or $\mathrm{R}^{2}=0$.

The values of a t test for the coefficients reveal that all independent variables in the model are insignificant at 0.05 or 0.1 . This means that $\mathrm{b} 1=\mathrm{b} 2=\mathrm{b} 3=\mathrm{b} 4=0$. In other words variations in water and soil pollution cannot be attributed to variations in the independent variables: monitoring, enforcement, organizational capacity and power and corruption. Tests for multicollinearity suggest non-multicollinearity based on values of VIF statistics are $<10$. Tolerance statistics value leads to the same conclusion.

The observed value of Durbin-Watson Statistics in Table 1 (2.357) is above the upper tabulated bound, therefore, we would not reject the null hypothesis of none-autocorrelated errors.

We can conclude from the results presented in Tables 25 and 26 that in general the three Ministries of Agriculture, Health and Environment are ineffective in achieving the goal of the environment policy of controlling water and soil pollution as a negative externality. Based on the estimated $\mathrm{R}^{2}$ and $\mathrm{P}$ values of coefficients suggest that the overall causal relationship between the four predictors of the model: monitoring, enforcement, government institutional capacity and corruption and power on one side and mitigating water and soil pollution in Jordan as a negative externality on the other, is weak.

Respondents in the sample were asked in the questionnaire to rank the motivations, according to their experience and opinion, behind government reluctance to allocate enough resources for the ministries to perform their environment tasks. According to their responses, general budget deficit stands as the most important reason. All government agencies actually face difficulties in obtaining their demands.

Change in government priorities was the second most important reason for not allocating enough funds to the environment agencies. Pressure from interest groups averse to government involvement in environmental issues ranked third.

The fourth rank was given according to the respondents in the sample to corruption. This has developed in Jordan gradually to become a phenomenon due to many causes, the most important being: the government not pursuing corrupt officials aggressively to avoid political instability, particularly since the "Arab Spring" events; government employees' salaries are at or below poverty line.

Corruption is not restricted to low level officials but it is higher among top management and even politicians. The last rank was assigned to change in interest and priorities of foreign donors. The rank says that there is no significant change on the donor side. 


\section{Major Findings}

\subsection{Deterrence Effect}

Table 1 shows that almost $75 \%$ of new investment projects were approved. This implies that their locations are far from water sources, communities and forests. However, this contradicts both the survey results and the actual situation where most of the investment projects of all types, are either within communities or on their borders with few exceptions especially major industrial areas.

\subsection{Monitoring Effects}

Monitoring generated low to moderate general impact. Table 3 demonstrates deterioration in monitoring activities. The performance of both regular and irregular inspections declined sharply or terminated completely. The frequency of inspections of major sources of pollution was few and symbolic. Table 6 reports a constant or declining number of inspections and facilities closed by the environment patrols. The justification by the Department was a shortage in resources and avoiding conflict with violators. Regression results indicated that power is blocking monitoring and enforcement implementation. Mean values of the opinions of sample of respondents representing top management officials in the three ministries presented in Table 16 reinforce the above findings. According to their answers, they disagree that monitoring activities of the ministries were effective and achieved the goals of the environment policy of mitigating negative externalities.

\subsection{Enforcement}

Data from the ministries reports and from the survey exhibit a low to moderate effect of enforcement instruments. For example, Table 2 shows that pollution from noise increases $45 \%$ during the last 3 years. Table 9 shows that confiscated vehicles loaded with untreated animal source fertilizers decreased while its use is increasing. Table 7 also depicts a decline in number of confiscated trucks loaded with trees taken illegally from the forests. This is in spite of the reports in the media on the alarming increase in cutting trees following significant rises in energy prices. Tables 11 to 14 show that $\mathrm{CO}_{2}$, GHG, N2O increased substantially. $\mathrm{CO} 2$ for instance increased by $39 \%$, GHG increased by $24 \%$, N2O and other gases increased by $50 \%$. The results suggest more air pollution and more negative externalities.

Table 16, reflecting opinions of the respondent sample covered by the survey, demonstrates that enforcement agencies were unsuccessful in protecting the environment and reducing negative externalities. Criminal law usually sets upper and lower limits of punishment; judges under various sources of pressure opt for the lower limit. Consequently, such sentences discourage environment officials because they realize that their efforts led to no serious consequences to the violators. For that reason the data shows a significant downward trend in the number of cases sent to be seen by courts. The influence of firms' managers and/or owners, who can override any serious threat or pressure to comply, also plays a significant rule in reducing agencies' effectiveness. Dislike of power effect and legal system ineffectiveness has led to the spread of corruption. This becomes another cause of ineffectiveness of environmental policy.

According to respondents, shortage in personnel, equipment, training and inappropriate control systems, databases and data analysis have controlled organizations' capabilities, consequently leading to inverse effect on environmental enforcement and conformity to regulations.

\section{Conclusions}

The empirical evidence obtained from this study suggests that the performance of the three ministries in the areas of monitoring and enforcement was in general statistically insignificant. Therefore the influence of both monitoring and enforcement activities was insufficient to mitigate negative externalities.

Their reasons for observed failure can be summarised as:

a. Lack of appropriate funding to environmental protection activities; namely monitoring and enforcement despite the generous donations from foreign governments, NGOs, and international organizations to the general budget.

b. Large industries and monopolies owned or managed by influential persons or groups do not comply or only partially comply with regulations.

c. Poor organizational capacity in the three ministries.

d. A sense of futility of expended effort among the employees based on their experience with the performance of law enforcement bodies represented by the governors and courts. This feeling encourages them to turn a blind eye to the violations to avoid trouble or in exchange for bribes. 
e. Environmental issues are not a top priority of the government, preoccupied with security issues and dealing with the unprecedented influx of refugees.

f. The political atmosphere in Jordan and in the region, the tribal form of governance and weakness of democratic institutions contributes to the failure of the agencies to perform better.

\section{Recommendations}

The study reveals that poor delineation of each of the three concerned ministries' duties and scope of responsibility has hindered the implementation of environmental policy. The laws of Ministries of Health, Agriculture and Environment should be reviewed considerably to omit overlap in responsibilities and duplication in effort. Most environmental protection duties should be solely allocated within the jurisdiction of the Ministry of Environment. Very specialized tasks that the MoE lacks the capabilities to perform, or naturally belong to other ministry, should be assigned to that ministry alone.

It is important for Jordan to have a comprehensive legal framework in place. The current legal system does not meet this requirement. Both foreign and Jordanian investors have serious concerns about judicial institutions. Therefore, they either avoid investment in Jordan, or invest under conditions that differences should be settled according to the foreign laws and courts. Both criminal and procedural laws require revision and modernization in the light of past experience and the experience of developed countries to remove all pitfalls and clarifying vague articles as possible.

Prescribed financial penalties and fines have become obsolete and insignificant because of inflation. At the same time, the authority of judges to choose the minimum of the range of imprisonment sentence should be controlled and the trade-off between imprisonment and fines should be accepted only in exchange for very high compensation Firms and individuals who commit serious and repeated violations and harm the environment should expect formidable punishment in order to achieve the required compliance level.

Effective monitoring and enforcement is costly. At the same time, disregarding the environment is more costly in both short and long run. Enough budget allocation and appropriate capacity building for environment protection agencies is a necessity for sustainable development.

The experience of developed countries has proven that the command and control approach is insufficient as a sole tool for environmental policy. The time has come for reconsidering price-based and rights-based measures in Jordan. This report provides practical policy review concerning the effectiveness and efficiency of alternative environmental policy instruments for greater environmental improvements.

Corruption should be confronted firmly by the government. At the same time the impact of unlawfully exerted influence on court proceedings and decisions as well as on administrative agencies should be controlled. Inequality in dealing with violators should be omitted.

These findings provide important preliminary evidence about the merits of environmental protection policy in achieving its pronounced goals. By highlighting the impact of monitoring and enforcement on measured environmental outcomes, this study aids both policy makers in Jordan as well as the various donor agencies that have been providing assistance to Jordan to mitigate negative externalities for several years.

\section{References}

Akullian, A., \& Kemp, C. (2006). Plastic Bag Externalities and Policy in Rhode Island. Enviromental Law and Policy. Brown Policy Review, Fall.

Alm, H. S. (2011). Designing Economic Instruments for the Environment in a Decentralized Fiscal System. Working paper, 1104.

Anderlini, L. A. (2000). Transaction costs and the robustness of the Coase Theorem. London WC2A 2AE: Southampton and Georgetown Universities \& London School of Economics and Political Science.

Anderson, J. E. (2010). Public policy making (7th ed.). Wadsworth Publishing, Boston, MA. USA.

Anderson, R. (2002). Incentive-Based Policies for Environmental Management in developing countries. Resources for the Future, 2(7), 1-10.

Andrews, C. (2006). Agent-based modeling of industrial ecosystems. (2014). Designing buildings for real occupants: An agent-based approach. IEEE Transactions on Systems, Man, and Cybernetics-Part A: Systems and Humans. http://dx.doi.org/10.1109/TSMCA.2011.2116116

Andrews., R. N. (1993). Environmental Policy in the Czech and Slovak Republic, Environment and Democratic Transition. Technology, Risk, and Society, 7, 5-48. 
Aubeeluck, H. (2013). Institutional Governance and Economic Growth, with special reference to Sub-Saharan Africa. African Studies Association of Australasia and the Pacific-AFSAAP, African Studies Association of Australasia and the Pacific-AFSAAP (1-14). Perth, Australia: African Renaissance and Australia.

Belliveau, R. T. (1999). Pollution trading and environmental injustice. Duke Environmental Law \& Policy Forum, 231-289.

Blackman, A. (2010). Alternative Pollution Control Policies in Developing Counries. Review of Environmental Economics and Policy, 4(2), 234-253.

Blackman, A. (2013). Alternative Pollution control policies in developing countries. Symposium: Environmental Quality and Economic Development.

Bovenberg L. A. (2002). Environmental taxation and regulation. Handbook of Public Economics. Elsevier Science, III , North-Holland.

Boyan, W. O. (1992). Political Theory in a Closed World: Reflections on William Ophuls, Liberalism and Abundance.

Brocas, I. (2013). Optimal allocation mechanisms with type-dependent negative externalities. Theory and Decision, 75(3), 359-387.

Calel, R. (2009). Environmental policy and public opinion:a note on instrument choice. Opticon, 1826(7), 1-5.

Cambridge Dictionaries Online. (2015). Cambridge, UK: Cambridge University Press.

Carlough, L. (2002). General Deterrence of Environmental Violation:A Peek into the Mind of the Regulated Public. Portland, Oregon: Department of Environmental Quality.

Christiansen, E. A. (2013). Negative externalities of food production: Discourses on the contested Norwegian aquaculture industry. Journal of Political Ecology, 20, 181.

Ciegis, R., \& Pusinaite, R. (2010). The negative externalities of the electricity industry and sustainability. Baltic Region, 1, 91-100. Retrieved from http://nbn resolving.de/urn:nbn:de:0168-ssoar-255469.

Conybeare, J. A. (1980). International organization and the Theory of Property Rights. University of Wisconson.

Cornes, R., \& Sandler, T. (1986). The Theory of Externalities, Public Goods, and Club Goods. FinanzArchive/Public Finance Analysis, 332-334.

Davies, J. C. (1998). Pollution Control in the United States: Evaluating. Washington, D.C.: Resources for the Future.

Decker, C. A. (2005). Adherence to Environmental Law: The Strategic Complementarities of Compliance Decisions. The Quarterly Review of Economics and Finance, 45(4-5), 641-661.

Defu, T. Y. ( 2013, May 20). Environmental Capital, Negative Externality and Carbon Finance Innovation. Chinese Journal of Population Resources and Environment, 9(2), 54-64.

Dietrich, E. (2004). Regulatory Factors Shaping Environmental Performance at Publicly-Owned Treatment Plants. Journal of Environment, Economics and Management, 148, 655-681.

Durwood Zaelke, M. S. (2005). Compliance, rule of law \& good governance, What Reason Demands: Making Law Work for Sustainable Development.

Earnhart, D. H. M. (2006). Shaping Corporate Environmental Behavior and Performance: The Impact of Enforcement and Non-Enforcement Tools. Washington, D. C.: EPA.

Earnhart, R. L. (2008). Effectiveness of government interventions at inducing better environmental performance: does effectiveness depend on facility or firm features? Boston College Environmental Affairs Law Review, 35(3), 478-511.

Elinor Ostrom, T. D. (2002). The drama of the Commons. Washington, DC: National Academy Press.

Ellerman, A. D. (2005). A Note on Tradeable Permits. Environmental \& Resource Economics, 123-131.

Ellig, J. A. (2010). The Quality and Use of Regulatory Analysis. Mercatus Center: George Mason University.

EPA, U. E. ( 2007). Compliance literature search results: Citations to over two hundred compliance-related books and articles from 1999 to 2007. Washington, D.C: U.S. Environmental Protection Agency . 
Foulon, J. L. (2002). Incentives for Pollution Control: Regulation or Information? Journal of Environmental Economic and Management, 44(1), 69-187.

Friedman, M. (n.d.). Social responsibility $>$ a waste of money.

Fullerton, D., Leicester, A., \& Smith, S. (2008). Environmental taxes. Oxford: Oxford University Press.

Ganguly, P. (n.d.). Environmental Pollution Regulations. Ostrava, Czech Republic: Center for Europian Studies, USB-Technical University of Ostrava.

Gaulding., D. R. (1995). Motivational underpinnings of command-and-control, market-based, and voluntarist environmental policies. Human Relations, 48(5), 439-465.

Gray \& Shadbegian, W. (2007). The Environmental Performance of Polluting Plants: A Spatial Analysis. Journal of Regional Science, 47(1), 63-84.

Gray, W., \& Shadbegian, R. (2005). When and why do plants comply? Paper mills in the 1980s. Law \& Policy, 27(2), 238-261.

Gruber, J. (2011). Public Finance and Public Policy (3rd ed.). Worth Publishers.

Guerin, K. (2003). Property Rights and Environmental Policy A New Zealand Perspective. New Zealand Treasury Working Paper, 1-38. Wellington, New Zealand: Zealand Treasury.

Gunningham, N. (2002). Beyond compliance: next generation environmental regulation. Melbourne: INSTITUT University of South Australia.

Gunningham, N. K. (2003). Shades of Green: Business, Regulation, and Environement. Stanford: Stanford University Press.

Gunningham, N. T. (2005). Motivating Management: Corporate Compliance in Environmental Protection. Law \& Policy, 27(2), 289-316.

Gunningham, N. (1994). Policing Pollution: Regulating the Chemical Industry. Australian Centre for Environmental Law.

Hammar, H. A. (2004). Political Economy Obstacles to Fuel. Energy Journal, 25(3), 1-17.

Hanna Zell, D. Q. (2010). Air pollution research: Visualization of research activity using density-equalizing mapping and scientometric benchmarking procedures. Journal of Occupational Medicine and Toxicology, $5(5), 1-9$.

Harrison, K. ( 2013a). The Political Economy of British Columbia's Carbon Tax, No. 63. OECD Publishing.

Harrison, K. (2013b). The Political Economy of British Columbia's Carbon Tax, No. 43. Canada, British Columbia. Retrieved from http://www.oecd.org/env/workingpapers.htm

Health, M. O. (2015). Annual report.

Heckenberg, R. W. (2012). Legislation, regulatory models and approaches to compliance and enforcement. Australian Research Council. Briefing Paper No. 6. Tasmania: University of Tasmania.

Helmut, W. (2002). Capacity Building in National Environmental Policy A Comparative Study of 17 Countries. New York: Springer-Verlag Berlin Heidelberg.

Heres, S. K. (2013). Understanding Public Support for Externality-Correcting Taxes and Subsidies: A Lab Experiment. Basque Center for Climate Change C3 Working Paper Series.

Hersh, T. D. ( 1999). Social Values in Environmental Regulation. Baltimore, MD: Johns Hopkins University Press.

Hertog, J. D. (2010). Review of economic theories of regulation. Utrecht School of Economics. Discussion Paper Series, 10-18. Utrecht, The Netherlands.: Utrecht School of Economics.

Hunter, S. (1996). Determining an agency's regulatory style: How does the EPA water office enforce the law? Western Political Quarterly, 45(2), 403-417.

Hurwicz, L. (1995). What is the Coase Theorem? Japan and the World Economy, 49-74.

Kay, J. V. (1990). Regulatory Reform: An Appraisal in Majone, Giandomenico (pp. 223-251). Deregulation or Re-regulation. London: Pinter Publishers.

Keats, M. A. (2005). Allocation of carbon emission certificates in power sector. Climate Change. 
Keith Brouhle, C. G. (2004). The Use of Voluntary Approaches for Environmental Policymaking in the U.S. Washington, DC.: U.S. Environmental Protection Agency, Working Paper Series, 04-05.

Keohane, M. ( 2006). Averting enforcement: Strategic response to the threat of environmental regulation. Working Paper. Retrieved from http://ssrn.com/abstract=935083 or http://dx.doi.org/10.2139/ssrn.935083

Khan, M. I. (2002). Economic Evaluation of Pesticide Use Externalities in the Cotton Zones of Punjab, Pakistan. The Pakistan Development Review, 41(4), 683-698.

Khanna, M. (2002). Corporate Environmental Management:Regulatory and Market-based Incentives. Land Economics, 78(4), 539-558.

Kompas, T., \& Gooday, P. (2007). The failure of 'command and control' approaches to fisheries management: lessons from Australia. International Journal Global Environmental Issues, 7(2-3), 174-191.

Krause, J. K. (1997). Introduction to Environmental Externality Costs. Boca Raton, FL, USA: CRC Press, Inc.

Kuminoff, V. N. (2007). Evaluating regulation and conservation policy for california's agri-environmental externalities. California Agroecosystem Services: Assessment, evaluation and policy perspectives. Davis: University of California.

Laplante, B. L. (2000). Economic Theory of Public Enforcement of Law. Journal of Economic Literature, 38(1), 45-76.

Lehmann, P. (2008). A review of economic literature. Leipzig, Germany: Helmholtz Center for Environmental Research.

Lubell, M. W. (2009). Collaborative watershed partnerships in the epoch of sustainability. In D. A. Mazmanian \& M. E. Kraft (Eds.), Toward sustainable communities transition and transformations in environmental policy (pp. 255-288). Cambridge, MA: MIT Press.

Macie, M., \& Maruyama, L. R. (2012). Energy, Pollutant Emissions and Other Negative Externality Savings from Curbing Individual Motorized Transportation. Energies, 5, 835-861.

Malloy, T. (2004). Innovation, Regulation and the Selection Environment. University of California.

Marc, H. S. (2006). Evaluating Effectiveness A framework for assessing management effectiveness of protected areas (2nd ed.). Cambridge, UK: IUCN, Gland, Switzerland and Cambridge, UK.

Maxwell, J. L. (2000). Self-regulation and social welfare: The political economy of corporate envoronmentalism. Journal of Law and Economics, XLIII.

Mazmanian, M. E. (2009). Toward Sustainable Communities: Transition and Transformations in Environmental Policy. MA: MIT Press.

Mazur, E. (2011). Environmental enforcement in decentralised governance systems: "Toward a nationwide level playing field". OECD Publishing.

Meffe, C. S. (1996). Command and Control and the Pathology of Natural Resource Management. Essays. 10(2), 328-337.

Miller, A. B. (2005). What Makes Companies Behave? An Analysis of Criminal and Civil Penalties Under Environmental Law. New York: Chicago Partners; New York University-Department of Economics.

Millock, K. C. (2004). Environmental taxes: A Comparison of French and Swedish Experience from Taxes on Industrial Air Pollution. Journal for Institutional Comparison, 2(1), 30-34.

Ministry of Environment. (2014a). Jordan's Third National Communication on Climate Change. UNDP.

Ministry of Environment. (2014b). Strategic Plan 2014-2016. Amman, Jordan: Ministry of Environment.

Ministry of Environment.. (2015). The Ministry of Environment. Retrieved 2015 2nd-December from The Ministry of Environment.

Morelli, J. (2011). Environmental Sustainability: A Definition for Environmental Professionals. Journal of Environmental Sustainability, 1-9.

Morgenstern, W. H. (2004). Economic Incentives versus Command and Control: What's the best approach for solving environmental problems? Resources Ecoincentives, (1), 13-17. 
Morita, S. (2006). A Review of empirical studies on environmental compliance. Seventh International Conference on Environmental Compliance and Enforcement (pp. 113-119). Washington, DC: Institute for Governance \& Sustainable Development;

Musgrave, R. A. ( 1989). Public finance in theory and practice (5th ed.). New York: McGraw Hill.

Nagler, M. G. (2011). Negative externalities, competition and consumer choice. The Journal of Industrial Economics, LIX(3), 396-421.

OECD. (2000). Reducing the risk of policy failure: challenges for regulatory compliance. OECD Publishing.

OECD. (2004). Conference on economic aspects of environmental aspects of evnvironmental compliance assurance. Global Forum on Sustainable Development, 1-21. Parise, France: OECD.

OECD. (2010). Environmental Performance Reviews. OECD Publishing.

OECD. (2013). Environment at a Glance. OECD Publishing.

Orr Karassin, A. O. (2009). From regulation to implementation: Responsive assessment of environmental compliance and enforcement. Journal of Environmental Assessment Policy and Management, 1-37.

Osman, F. A. (n.d.). Public policy making: Theoriesand their implicationsin developing countries. Asian Affairs, 37-53.

Pascoe, F. B. (2004). Environmental Compliance and Enforcement Indicators:Environment Canada Pilot Projects-Addressing Challenges. Environment Canada.

Persson, Å. (2004). Policy Integration for Sustainability. Stockholm Environment Institute.

Portney, P. R. (2000). Public Policies for Environmental Protection. In E. P. Stavins (Ed.), Public Policies for Environmental Protectio (2nd ed. pp. 1-9). Washington: Resources for the Future Press.

Quality, S. O. (2004). General deterrence of environmental violation: A peek into the mind of the regulated public. Portland: Oregon Department of Environmental Quality.

Rassier, D. (2006). Do trade unions affect compliance with environmental regulation? Bureau of Economic Analysis

Rist, J. Z. (2004). Ten step to a results based monitoring and evaluation system. Washington, D.C.: The World Bank.

Robinson, J. (2002). A review of economic instruments for environmental management in Queensland. Retrieved from http://www.coastal.crc.org.au/pdf/economic_instruments.pdf

Russell, C. (1990). Monitoring and Enforcement, in Public Policies for Environmental for Environmentall Protection. Washington, DC: Resources for the future.

Shakeb Afsah, A. B. (2013). Environmental regulation and public disclosure. RFF Press.

Shimshack, J. \&. (2006). Enforcement \& over-compliance. Economic Inquiry, 44(2), 352-366.

Shimshack, J. P. (2005). Regulator reputation, enforcement, and environmental compliance. Journal of Env. Economics and Management, 50, 519-540.

Smith, S. (1992). Taxation and the environment: a survey. Fiscal Studies, 13(4), 21-57.

Smith, V. C. (n.d.). Externality-correcting taxes and regulation. Norway: Department of Economics, University of Oslo. JEL Classification numbers: H21, H23.

Stafford, S. (2003). Assessing the Effectiveness of State Regulation and Enforcement of Hazardous Waste. Journal of Regualtory Economics, 23(1) .

Stafford, S. (2005). Does Self-Policing Help the Environment? EPA's Audit Policy and Hazardous Waste Compliance. Vermont Journal of Environmental Law, 6.

Stafford, S. (2006). Rational or confused polluters? Evidence from hazardous waste compliance. Economic Analysis \& Policy, 5(1).

Stavins, R. N. (2001). Experience with market-based environmental policy instruments. Resources for the Future 1616 P Street, NW Washington, D. C. 20036.

Stavins, R. N. (2001). Lessons From the American Experiment With Market-Based Environmental policies. Washington, D.C.: Resources for the Future. 
Stéphane, J. G. (2007). Regulatory Management Systems Across OECD Countries. OECD Publishing.

Stevenes, R. (2003). Cost Heterogeneity and the Potential Savings from Market-Based Policies. Journal of Regulatory Economics, 23(1), 43-59.

Stranlund, J. (1999). Endogenous monitoring and enforcement of a transferable emissions permit system. Journal of Environmental Economics and Management, 38, 267-282.

Taussig, S. (1984). Principles of Environmental Economics and Sustainability: An Integrated Economic and Ecological Approach (3rd ed.). Englewood Cliffs: Prentice-Hall.

Taylor, A. R. (2011). Global warming and economic externalities. Economic Theory, 329-351.

The Enviroment Law no.52. (2006). The Environment Law no.52. Amman: The Government of Jordan.

The European Parliament and the Council of European Union. (2008). Directive of the European Parliament and of the Council concerning integrated pollution prevention and control. Official Journal of the European Union, 8-29.

The Ministry of Agriculture. (2014). The Ministry of Agriculture annual report.

The Ministry of Environment. (2006). The Environment Law no. 52. The Environment Law no.52. Amman, Jordan, Jordan: The Ministry of Environement.

The Ministry of Environment. (2014). Jordan's third national communication on climate change. The United Nations Framework Convention on Climate Change.

The Ministry of Health. (n.d.). The Ministry of Health. Retrieved January 15, 2015, from The Ministry of Health.

The World Bank. (2000). Incentives for pollution control-regulation and public disclosure. No. 2291. Washington, D.C.: The World Bank,

Thornton, D. G. (2005). Deterrence and corporate environmental behavior. Law and Policy, 25(2), 262-288.

Tresch, R. W. (2008). Public sector economics. Publisher: Palgrave Macmillan.

Ulbrich, H. H. (2011). Public finance in theory and practice. New York: Routledge, Taylor \& Francis Group.

UNEP. (2004). The use of economic instruments in environmental policy:opportunities and challenges. United Nations Publication, UNEP/ETB/2003/9.

Videras, J. (2000). The appeal of voluntary environmental programs: which firms participate and why? Contemporary Economic Policy, 18(4), 449-461.

Viscusi, J. M. (2005). Economics of Regulation and Antitrust (4th ed.). Cambridge Center: MIT Press.

Watermelon is ripe. (2015). Al Rai Newspaper. Amman, Jordan: Al Rai Press.

Whitehead, B. W., \& Stavins, R. N. (1996). The next generation of market-based environmental policies. Discussion Paper 97-10 Prepared for Environmental Reform: The Next Generation, Resources for the Future (pp. 1-45). Washington: Resources for the Future.

Winston, D. C. (2007). Green to cold. Concordville, PA: Soundview Executive Book Summaries.

Zannetti, A. D. (2007). An Introduction to air pollution, definitions, classifications, and history. In D. A. A. R. P. Zannetti (Ed.), Ambient Air pollution (pp. 1-14). Fremont, CA (USA): The Arab School for Science and Technology (ASST) \& The Enviro Comp Institut.

Zasloff, J. (2013). A new Feast for Environmental Policy Wonks. Journal of Economic Perspectives, 5.

\section{Copyrights}

Copyright for this article is retained by the author(s), with first publication rights granted to the journal.

This is an open-access article distributed under the terms and conditions of the Creative Commons Attribution license (http://creativecommons.org/licenses/by/3.0/). 